\title{
Encapsulation of Carlina acaulis essential oil and carlina oxide to develop long-lasting mosquito larvicides: microemulsions versus nanoemulsions
}

\author{
Roman Pavela ${ }^{1,2} \cdot$ Lucia Pavoni $^{3} \cdot$ Giulia Bonacucina $^{3} \cdot$ Marco Cespi $^{3} \cdot$ Loredana Cappellacci $^{3} \cdot$ Riccardo Petrelli $^{3}$. \\ Eleonora Spinozzi ${ }^{3} \cdot$ Cristina Aguzzi $^{3} \cdot$ Laura Zeppa $^{3} \cdot$ Massimo Ubaldi $^{3} \cdot$ Nicolas Desneux $^{4} \cdot$ Angelo Canale $^{5}$. \\ Filippo Maggi ${ }^{3}$. Giovanni Benelli ${ }^{5}$
}

Received: 15 August 2020 / Revised: 21 November 2020 / Accepted: 29 December 2020 / Published online: 5 February 2021

(c) The Author(s) 2021

\begin{abstract}
Carlina acaulis root essential oil (EO) is one of the most potent mosquito larvicides ( $\mathrm{LC}_{50}<2 \mathrm{ppm}$ ). This EO is mainly composed of carlina oxide (>90\%). Poor water solubility and rapid degradation from UV light and oxygen in the environment limit the real-world use of this EO. Herein, we developed nanocarrier-based formulations, namely micro- and nanoemulsions (ME and NE, respectively) containing C. acaulis EO or carlina oxide (both at $0.5 \%$ ) as active ingredients (a.i.). The larvicidal activity of ME and NE was evaluated against Culex quinquefasciatus. The highest larvicidal activity was achieved by the ME containing $0.5 \%$ of the $\mathrm{EO}(\mathrm{M} 1)$; its $\mathrm{LC}_{50(90)}$ was 579.1 (791.3) $\mu \mathrm{L} \mathrm{L}^{-1}$. Sublethal effects of this $\mathrm{ME}$ and its a.i. were assessed testing both at the $\mathrm{LC}_{16}, \mathrm{LC}_{30}, \mathrm{LC}_{50}$ and $\mathrm{LC}_{90}$ on mosquito larvae exposed to each product for 1-7 $\mathrm{h}$, and then monitoring mortality for 18 days. At variance with the $\mathrm{EO}, \mathrm{ME}$ application, even at $\mathrm{LC}_{16}$, led to $100 \%$ mortality at 18 days. The EO and its encapsulated form were scarcely toxic to human keratinocytes (HaCaT) and human fibroblast (NHF A12) cell lines. The acute toxicity of $C$. acaulis EO and its ME (M1) was also evaluated in Wistar rats through oral administration; EO LD 50 was $1098 \mathrm{mg} \mathrm{kg}^{-1}$ bw, whereas its ME, even at $5000 \mathrm{mg} \mathrm{kg}^{-1}$ bw (considered the upper testing limit to establish safety to mammals), was not toxic. This study highlights the outstanding efficacy of $C$. acaulis EO ME for developing longlasting and safe larvicides against $C x$. quinquefasciatus.
\end{abstract}

Keywords Botanical pesticides $\cdot$ Culex quinquefasciatus $\cdot$ Filariasis $\cdot$ Mosquito control $\cdot$ Non-target effects $\cdot$ Sublethal toxicity

\section{Key message}

- Carlina acaulis essential oil (EO) and its main constituent carlina oxide (CO) are effective larvicides against

Communicated by Murray Isman.

Roman Pavela and Lucia Pavoni have contributed equally to this work.

Filippo Maggi

filippo.maggi@unicam.it

$\triangle$ Giovanni Benelli

giovanni.benelli@unipi.it

1 Crop Research Institute, Drnovska 507, 16106 Ruzyne, Prague 6, Czech Republic

2 Department of Plant Protection, Czech University of Life Sciences Prague, Kamycka 129, 16500 Suchdol, Praha 6, Czech Republic Culex quinquefasciatus; herein, both were formulated in

3 School of Pharmacy, University of Camerino, 62032 Camerino, Italy

4 Université Côte d'Azur, INRAE, CNRS, UMR ISA, 06000 Nice, France

5 Department of Agriculture, Food and Environment, University of Pisa, via del Borghetto 80, 56124 Pisa, Italy 
micro- and nanoemulsions (ME and NE) containing $0.5 \%$ of $\mathrm{EO}$ or $\mathrm{CO}$ as active ingredient against $C x$. quinquefasciatus.

- EO-based ME was the most effective larvicide, with $\mathrm{LC}_{50(90)}$ of $579.1(791.3) \mu \mathrm{L} \mathrm{L}^{-1}$

- The EO and its ME were tested at $\mathrm{LC}_{16}, \mathrm{LC}_{30}, \mathrm{LC}_{50}$ and $\mathrm{LC}_{90}$ on larvae exposed for $1,2,3,4,5,6$ and $7 \mathrm{~h}$, and then monitored for 18 days; ME at the lowest LC tested $\left(\mathrm{LC}_{16}\right)$ led to $100 \%$ insecticidal efficacy at 18 days.

- The EO and its ME tested on human keratinocytes (HaCaT) and human fibroblast (NHF A12) cell lines showed little toxicity. On rats, the $C$. acaulis EO $\mathrm{LD}_{50}$ was $1098 \mathrm{mg} \mathrm{kg}^{-1} \mathrm{bw}$, while its $\mathrm{ME}$, even at $5000 \mathrm{mg} \mathrm{kg}^{-1}$ bw, was not toxic.

- This ME represents an effective and safe formulation for $C x$. quinquefasciatus management.

\section{Introduction}

Developing highly effective insecticides, acaricides and arthropod repellents is a challenge of high economic importance nowadays (Isman 2015; Stevenson et al. 2017; Benelli and Pavela 2018a, b; Chaieb et al. 2018; Benelli et al. 2019a; Petrović et al. 2019). The widespread overuse of synthetic pesticides leads to severe non-target effects on human health and the environment (Desneux et al. 2007; Benelli et al. 2021a). In this framework, research on green pesticides from natural products, e.g. essential oil (EO)-based ones, is of timely importance, since the multiple mode of action of EO constituents reduces the likelihood of resistance development in targeted arthropods (Jankowska et al. 2018, 2019). EOs toxicity on non-target species is often limited, allowing their use for biocontrol purposes (e.g. Govindarajan et al. 2016, Benelli et al. 2019b, c; Pavela et al. 2020a, but see also Pavela 2014). Of note, despite a huge number of research products on the topic (Isman and Grieneisen 2014; Chellappandian et al. 2018), moving plant-based insecticides from laboratory to the field is still difficult, due to both formulation and regulatory issues (Pavela et al. 2019a). Concerning the former, it should be noted that EOs chemical composition is difficult to standardize and their efficacy in the field is often limited to a short period of time due to the high volatility, low stability and photo- and thermal degradation of the EO mixture once exposed into the environment (Pavela and Benelli 2016).

Nanoencapsulation technology represents one of the most promising tools for the utilization of plant EOs as active ingredients for a wide array of purposes. The nanoencapsulation approach could improve the EOs physico-chemical properties and stability, by enabling their water dispersibility, reducing their volatility and by protecting them from the environment interaction (Pavoni et al. 2020). Among the most promising nanosystems, micro- and nanoemulsions (MEs and NEs, respectively) are the easiest to formulate and handle. Furthermore, they can be obtained at low costs (Pavoni et al. 2019a, b). MEs and NEs are self-emulsifying colloidal systems composed of two immiscible liquid phases. Despite the prefixes '-micro' and '-nano', the internal phase of both MEs and NEs is a dispersion of nanometric droplets in the external/continuous medium (Anton and Vandamme 2011). They differ mainly in terms of quantitative composition and free energy of the system. This latter is an influential parameter on their preparation, formulation and stability (Pavoni et al. 2020). In particular, NEs show a lower surfactant-to-oil ratio (SOR), generally between 1 and 2, relative to MEs (SOR > 2) (Rao and McClements 2011), that is advantageous in terms of safety and sustainability. On the contrary, MEs are favoured since they form spontaneously, while NEs require an external input in order to overcome the energy barriers of such system (McClements 2012).

MEs and NEs are optimal vehicles for lipophilic or low water-soluble compounds, such as EOs, that require the dispersion in water media, i.e. pesticides (Pavoni et al. 2019b). Moreover, they could enhance the bioavailability, and thus the effectiveness, of active compounds through their solubilization into small oily droplets (Pavoni et al. 2019a, b; Sugumar et al. 2014).

Carlina acaulis L., also known as 'piccolo cardo' (little thistle, stemless carline thistle) or 'carciofo selvatico' (wild artichoke), is a monocarpic perennial herb, which grows on dry and calcareous soils in the mountains of southern and central Europe, from 700 to $2000 \mathrm{~m}$ of altitude (Tutin et al. 1976). The name of 'Carlina' seems to have its origins from the age of Carlo Magno, who used the plant for the treatment of plagues, while in the opinion of other authors, the name derives from the distortion of the word 'cardina', which means 'little thistle'. The name 'acaulis' alludes to the fact that the plant lacks a stem. $C$. acaulis has pinnate, hard, thorny leaves growing in a basal rosette, showy capitula that reach $10-12 \mathrm{~cm}$ in diameter and a very short stem (Fig. 1) (Pignatti 1982). The medical use of $C$. acaulis has a very long history in Europe. Theophrastus described that the cooked root of the so-called Chamaeleon albus was useful for the treatment of skin exudates, while its dried form was useful for anthelmintic control (Hort 1949). The use of carlina juice was also recommended by Pliny mixed with wine for the treatment of tuberculosis (Ruellio 1522). Moreover, the root was recommended by Krzysztof Kluk for its activity on the uterus and for its anthelmintic and diaphoretic activity, but also for the treatment of infections (Kluk 1805). The historical use of this plant for the treatment of different pathologies is also confirmed by the fact that the monographs of Radix Carlinae are enclosed in several official pharmacopoeias of European countries (Stojanović-Radić et al. 2012). 
Fig. 1 Carlina acaulis (left), the essential oil obtained from roots (centre) and its bioactive compound, carlina oxide (right)

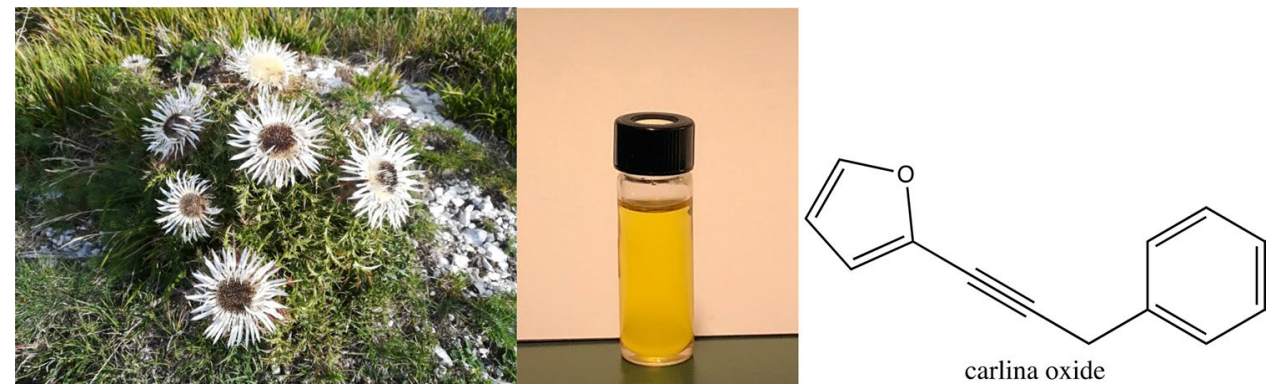

According to its long curative history, C. acaulis is still largely used as a traditional medicinal plant in several countries. For instance, the decoction of its root is used in Italy as a cholagogue, diuretic, tonic, anti-oedematous, anicteric, antibiotic and against cold (Guarrera et al. 2003; Menale et al. 2006; Strzemski et al. 2017). The aerial parts are used in Montenegro, Serbia and Bosnia Herzegovina for the cure of gastritis (Redžić 2007); the roots, flowers and stems are largely used in Macedonia to treat acne, eczema and other skin diseases (Rexhepi et al. 2013). The root hydro-alcoholic extracts are used for veterinary preparations as wound healing and antiseptic (Committee for Veterinary Medicinal Products 1999).

The Italian list of botanicals used in food supplements and the Belfrit list (Cousyn et al. 2013) include C. acaulis root and its EO, that are described as diaphoretic, eupeptic, diuretic and carminative. From the roots of $C$. acaulis different constituents have been extracted and characterized: inulin, EO, tannins, triterpenes and chlorogenic acids (Chalchat et al. 1996; Vitkova and Evstatieva 2002; Jaiswal et al. 2011; Stojanović-Radić et al. 2012; Strzemski et al. 2017). In particular, from the analysis of the EO composition, it has been found that the main constituent is the polyacetylene 2-(3-phenylprop-1-yn-1-yl)furan, also known as carlina oxide (MF: $\mathrm{C}_{13} \mathrm{H}_{10} \mathrm{O}$, MW: 182) (Fig. 1), which was isolated in 1889 , becoming one of the oldest known members of the polyacetylenes family (Semmler 1889; Chalchat et al. 1996; Stojanović-Radić et al. 2012; Benelli et al. 2019b).

The $C$. acaulis EO showed different biological activities, including a highly promising insecticidal potential, which is increasingly capturing the attention of scientists (Benelli et al. 2019b; Pavela et al. 2020a, b; Benelli et al. 2021b), along with antimicrobial and antiprotozoal activities (Dordević et al. 2007; Herrmann et al. 2011; StojanovićRadić et al. 2012).

Being highly active against several insect species and composed almost exclusively of a single constituent, i.e. carlina oxide, this EO represents a rather unique natural product that deserves further efforts to allow its practical use in insecticide formulations. However, the use of $C$. acaulis EO and carlina oxide as new green insecticides is limited by their high lipophilicity and volatility as well as susceptibility to chemical degradation that reduce their persistence and diffusion in the environment. In this framework, formulating effective and highly stable micro- and nanoemulsions can represent a valuable approach to allow the practical employ of $C$. acaulis $\mathrm{EO}$ or carlina oxide as active ingredients for developing commercial mosquito larvicides. Furthermore, some researchers recently succeeded in developing a field cultivation of $C$. acaulis where the plants were found to produce carlina oxide in the roots (Strzemski et al. 2020), thus making the manufacture of the active ingredient from cropping quite sustainable. On the other hand, in vitro and hydroponic cultures failed to produce this polyacetylene.

In the present study the EO was obtained from a commercial batch of $C$. acaulis roots by hydrodistillation and analysed through GC-MS; then its major constituent (>90\%) carlina oxide was isolated. Both the EO and carlina oxide were formulated into ME and NE and testedalone or emulsified-for acute toxicity against larvae of $C x$. quinquefasciatus Say (Diptera: Culicidae), a major filariasis vector (Wilke et al. 2020). As the field use of the developed formulations as larvicides is unlikely to guarantee uniform dispersion in the environment, thus failing to achieve the required concentrations-ideally $\geq \mathrm{LC}_{90}$, we subsequently studied the effect of sublethal concentrations of the most efficient formulation (i.e. $\mathrm{LC}_{16}, \mathrm{LC}_{30}, \mathrm{LC}_{50}$ and $\mathrm{LC}_{90}$ ) and various exposure times (i.e. 1, 2, 3, 4, 5, 6 and $7 \mathrm{~h}$ ) on subsequent larval mortality as well as successful adult emergence (\%). Lastly, the ME/NE showing the highest efficacy against $C x$. quinquefasciatus larvae was selected-along with the $C$. acaulis EO-for acute oral toxicity experiments on Wistar rats and for dermal toxicity on human keratinocytes and fibroblasts, to shed light on the possible toxicity of both products on a vertebrate and cell models and to provide new insights to fulfil the requirements of regulatory agencies. 


\section{Materials and methods}

\section{Plant material}

A batch (code MP0136, no C-010818091018) of the roots of $C$. acaulis was acquired from A. Minardi \& Figli S.r.l. (Bagnacavallo, RA, Italy). These plant roots were from a spontaneous Albanian accession harvested in 2018.

\section{Essential oil isolation}

One $\mathrm{kg}$ of dry roots of $C$. acaulis was crushed using a shredder (Albrigi, mod. E0585, Stallavena, Verona, Italy) and then put into a $10 \mathrm{~L}$ round flask, which was filled with $7 \mathrm{~L}$ of distilled water. The roots were left to soak overnight. After that time, they were subjected to hydrodistillation with a Clevenger-type apparatus for $8 \mathrm{~h}$. This time was selected due to the relatively low volatility of the main EO constituent (carlina oxide). The heating apparatus consisted of a mantle system Falc MA (Falc Instruments, Treviglio, Italy). The root EO, obtained in $0.78 \%$ yield (w/w), showed a pale orange colour (Fig. 1) and a density higher than water $(\sim 1.4 \mathrm{~g} / \mathrm{mL})$. After hydrodistillation, it was decanted and then separated from the aqueous layer. The $\mathrm{EO}$ was therefore dehydrated with anhydrous $\mathrm{Na}_{2} \mathrm{SO}_{4}$, collected in vials closed with PTFE/silicon caps and kept at $4{ }^{\circ} \mathrm{C}$ until chemical analysis and biological assays. In order to assure the sufficient amount of EO for the successive experiments, the above EO isolation procedure was repeated thrice.

\section{GC-MS analysis on Carlina acaulis essential oil}

The analysis of $C$. acaulis EO was conducted using an Agilent $6890 \mathrm{~N}$ gas chromatograph furnished of a single quadrupole $5973 \mathrm{~N}$ mass spectrometer and an autosampler 7863 (Agilent, Wilmington, DE). The separation was achieved using an HP-5 MS capillary column (30 m length, $0.25 \mathrm{~mm}$ i.d., $0.1 \mu \mathrm{m}$ film thickness; $5 \%$ phenylmethylpolysiloxane), supplied by Agilent (Folsom, CA, USA). The column was allowed to reach the temperature of $60{ }^{\circ} \mathrm{C}$ for $5 \mathrm{~min}$, raised up to $220{ }^{\circ} \mathrm{C}$ at $4{ }^{\circ} \mathrm{C} \mathrm{min}-1$ and then up to $280{ }^{\circ} \mathrm{C}$ at $11^{\circ} \mathrm{C} \mathrm{min}{ }^{-1}$ for $15 \mathrm{~min}$. The injector and detector had a temperature of $280{ }^{\circ} \mathrm{C}$. The mobile phase was constituted of $99.9 \%$ of $\mathrm{He}$ and its flow was of $1 \mathrm{~mL} \min ^{-1}$. The EO was diluted 1:1000 in $n$-hexane; then $1 \mu \mathrm{L}$ was injected in split mode (1:50). The acquisition of peaks was achieved with the electron impact (EI, $70 \mathrm{eV}$ ) mode in the range $29-400 \mathrm{~m} \mathrm{z}^{-1}$. Chromatograms were analysed using the MSD ChemStation software (Agilent,
Version G1701DA D.01.00) and with the NIST Mass Spectral Search Program v. 2.3. The components of the EO were identified with the interactive combination of the temperature-programmed retention indices (RIs) and mass spectra (MS), in comparison with those of ADAMS, NIST17 and FFNSC3 libraries (Adams 2007; NIST 17, 2017; FFNSC 2015). The calculation of RI was done using a mix of $n$-alkanes $\left(\mathrm{C}_{7}-\mathrm{C}_{30}\right.$, Sigma-Aldrich, Milan, Italy), using the Van den Dool and Kratz (1963) formula.

\section{Purification of carlina oxide from essential oil}

$1.505 \mathrm{~g}$ of C. acaulis EO was purified by silica gel $(80 \mathrm{~g})$ column (70-230 mesh, $60 \AA$, Merck) chromatography using $100 \%$ of $n$-hexane. A total of 174 fractions were collected and checked using thin-layer chromatography (TLC). From fractions $80-174,1.2 \mathrm{~g}$ of pure carlina oxide was isolated.

\section{NMR analysis of the pure carlina oxide}

The NMR spectra of carlina oxide were acquired using a Bruker Avance 400 Ultrashield spectrometer. All the chemical shift values were reported in $\delta$ values (ppm), while the coupling constants $(J)$ in hertz. The internal standard used for the analysis was tetramethylsilane (TMS). Proton chemical data were expressed as chemical shift, multiplicity ( $\mathrm{s}=$ singlet, $\mathrm{d}=$ doublet, $\mathrm{dd}=$ doublet of doublets, $\mathrm{t}=$ triplet, $\mathrm{dt}=$ doublet of triplets, $\mathrm{q}=$ quartet, $\mathrm{m}=$ multiplet, brs $=$ broad singlet) coupling constant (s), integration. The NMR sample was prepared diluting the EO $(20 \mathrm{mg})$ in deuterated chloroform. For H, HSQC-DEPT, HMBC and COSY experiments standard Bruker library pulse programs were employed. The NMR data obtained were comparable to the data reported in the literature (Benelli et al. 2019b).

\section{Preparation of micro- and nanoemulsions}

Ethyl oleate (Crodamol ${ }^{\mathrm{TM}}$ EO), Polysorbate 80 (TEGO ${ }^{\circledR}$ SMO 80; Evonik Industries, Essen, DE) and vegetable glycerol were provided by ACEF (Fiorenzuola d'Arda, IT). Deionized water and ethanol $96 \%$ were standard reagent grade. MEs were prepared following the procedures reported by Cespi et al. (2017) for the Smyrnium olusatrum L. EO, through a process of spontaneous emulsification deriving from the mixing of an aqueous and an oily phase. Distilled water was added dropwise to the oily phase placed under magnetic stirring, in the required amount to attain the final concentration. The oily phase was composed of EO or a mixture of EO-ethyl oleate, Polysorbate 80, and of an alcoholic phase composed of glycerol and ethanol, at 6:1 ratio. NEs were obtained through a high-energy method, by using 
Table 1 Composition (\%) of microemulsions (M1-M2), nanoemulsion (N1-N2) and micro-/nanoemulsion controls $\left(C_{\mathrm{M}}-C_{\mathrm{N}}\right)$ tested in this study

\begin{tabular}{llllll}
\hline Sample & $\begin{array}{l}\text { Polysorbate } \\
80\end{array}$ & $\begin{array}{l}\text { Alco- } \\
\text { holic } \\
\text { phase* }\end{array}$ & \begin{tabular}{l} 
Active ingredient \\
\cline { 5 - 6 }
\end{tabular} & $\begin{array}{l}\text { C. acaulis } \\
\text { essential } \\
\text { oil }\end{array}$ & Carlina oxide \\
& & & & \\
\hline $\mathrm{M} 1$ & 13 & 35 & 0.5 & - & 51.5 \\
$\mathrm{M} 2$ & 13 & 35 & - & 0.5 & 51.5 \\
$C_{\mathrm{M}}$ & 13 & 35 & - & - & 52 \\
$\mathrm{~N} 1$ & 0.33 & - & 0.5 & - & 99.17 \\
$\mathrm{~N} 2$ & 0.33 & - & - & 0.5 & 99.17 \\
$C_{\mathrm{N}}$ & 0.33 & - & - & - & 99.67 \\
\hline
\end{tabular}

*The alcoholic phase is composed of $30 \%$ glycerol and 5\% ethanol $96 \%$

a high-pressure homogenizer. They were prepared according to the literature (Cappellani et al. 2018). Briefly, C. acaulis EO was added dropwise to a surfactant aqueous solution under high-speed stirring (Ultraturrax T25 basic, IKA® Werke GmbH \& Co.KG, Staufen, Germany) for $5 \mathrm{~min}$ at $9500 \mathrm{rpm}$. The obtained emulsion was then subjected to a homogenization process by means of French Pressure Cell Press (American Instrument Company, AMINCO, Maryland) for four cycles at the pressure of $130 \mathrm{MPa}$. Compositions of MEs, NES and their relative controls are reported in Table 1.

\section{Characterization of micro- and nanoemulsions}

Visual inspection of formulations was done by a polarizing optical microscope (MT9000, Meiji Techno Co Ltd, JP) equipped with a 3-megapixel CMOS camera (Invenio 3S, DeltaPix, DK). Particle size measurements were performed through a dynamic light scattering (DLS) technique. DLS analyses were carried out using a Zetasizer nanoS (Malvern Instrument, UK) equipped with a backscattered light detector working at $173^{\circ}$. Samples $(1 \mathrm{~mL})$ were inserted into disposable cuvettes and analysed at $25^{\circ} \mathrm{C}$, following a temperature equilibration time (180 s). The analyses were performed at different time points: 0 day (t0), 1 month (t1), 3 months (t3) and 6 months (t6).

\section{Mosquito rearing}

The tested mosquitoes, Cx. quinquefasciatus, were from an established laboratory colony at the Crop Research Institute (Prague, Czech Republic); Cx. quinquefasciatus individuals were reared under controlled conditions for more than 20 generations, and never exposed to insecticides before the experiments. Larvae were fed on dog biscuits and yeast powder in a 3:1 ratio, and held at $25 \pm 2{ }^{\circ} \mathrm{C}, 70 \pm 5 \% \mathrm{RH}$, and a photoperiod of 16:8 (L:D) h.

\section{Larvicidal activity on Culex quinquefasciatus}

The acute toxicity, measured as mortality after $24 \mathrm{~h}$ of exposure, was determined for early 3rd instar larvae of $C x$. quinquefasciatus. Mosquito larvicidal assays were carried out according to WHO Standard Procedures (1996), with slight modifications (Benelli et al. 2018a, b). The EO was diluted in dimethyl sulphoxide (DMSO) to prepare a serial dilution of test concentrations. For experimental treatment, $1 \mathrm{~mL}$ of serial dilutions was added to $224 \mathrm{~mL}$ of distilled water in a 500-mL glass bowl and shaken lightly to ensure a homogenous test solution at concentration $0.3 ; 0.5 ; 0.8$; $1.0 ; 1.5$ and $1.8 \mu \mathrm{L} \mathrm{L}^{-1}$. The efficacy of the MEs and NEs (M1, M2, N1 and N2) was tested in the same manner as above, except that the MEs and NEs were mixed into the water directly (i.e. without the use of DMSO) to obtain a serial dilution of $200,400,600,800$ and $1000 \mu \mathrm{L} \mathrm{L}^{-1} . C_{\mathrm{M}}$ and $C_{\mathrm{N}}$ were tested as negative controls for $\mathrm{ME}$ and $\mathrm{NE}$, respectively. Water plus DMSO at the maximum amount used to formulate the active ingredient was tested as negative control in EO and carlina oxide experiments. In all cases, the selected mosquito larvae were transferred in distilled water into a bowl of the prepared test solution with a final surface area of $125 \mathrm{~cm}^{2}$ (25 larvae beaker ${ }^{-1}, 4$ replications). The assays were placed in a growth chamber (16:8 (L:D), $25 \pm 1{ }^{\circ} \mathrm{C}$ ). Mortality was determined after $24 \mathrm{~h}$ of exposure, no food was offered to the larvae.

\section{Sublethal toxicity on Culex quinquefasciatus}

The effect of different LC concentrations and different exposure times on larval and pupal mortality and on the percentage of new emerged $C x$. quinquefasciatus adults were tested as follows. The $\mathrm{LC}_{16}, \mathrm{LC}_{30}, \mathrm{LC}_{50}$ and $\mathrm{LC}_{90}$ estimated for the most effective larvicidal emulsion (M1) and its active ingredient $C$. acaulis $\mathrm{EO}$ were tested on $3^{\text {rd }}$ instar larvae of Cx. quinquefasciatus (200 larvae replicate ${ }^{-1}$ ) exposed to both products for 1, 2, 3, 4, 5, 6 and $7 \mathrm{~h}$. The application methods are described in the paragraph above for the acute toxicity test. Then, they were transferred to clean water tanks $(35 \times 35 \times 50 \mathrm{~cm})$ and provided with standard diet. The mortality was evaluated every day for eighteen days. Larvae mortality during the development period, total larval and pupae mortality, and percentage of emerged adults of $C x$. quinquefasciatus were determined. Mosquito mortality or adults emerged were expressed as mean values $(\%) \pm$ SE. Four replicates were done for each concentration. The treated insects were placed in a growth chamber $\left[25 \pm 1{ }^{\circ} \mathrm{C}\right.$; 16:8 (L:D)]. 


\section{Dermal toxicity of $C$. acaulis essential oil and its microemulsion}

\section{Cell lines}

Immortalized human keratinocytes cell line (HaCaT) was cultured in DMEM supplemented with $10 \%$ fetal bovine serum (FBS), $2 \mathrm{mM}$ L-glutamine, $100 \mathrm{IU} \mathrm{mL}^{-1}$ penicillin/ streptomycin and maintained at $37{ }^{\circ} \mathrm{C}$ with $5 \% \mathrm{CO}_{2}$ and $95 \%$ humidity. Primary human fibroblast cell line (NHF A12) was cultured in DMEM supplemented with $10 \%$ fetal bovine serum (FBS), $2 \mathrm{mM}$ L-glutamine, $100 \mathrm{IU} \mathrm{mL} \mathrm{mL}^{-1}$ penicillin/ streptomycin and maintained at $37^{\circ} \mathrm{C}$ with $5 \% \mathrm{CO}_{2}$ and $95 \%$ humidity. Both cell lines were furnished by IFOM (Rome, Italy).

\section{MTT assay}

Three thousand cells per well were seeded in 96-wells plate in a final volume of $100 \mu \mathrm{L}$ well ${ }^{-1}$. After one day of incubation, $C$. acaulis EO (1.69-863.74 $\left.\mathrm{g} \mathrm{mL}^{-1}\right)$, the microemulsions (M1 and $C_{\mathrm{M}}, 205.08-105,000 \mu \mathrm{g} \mathrm{mL}^{-1}$ ) and vehicles were added, and six replicates were used for each treatment. After $24 \mathrm{~h}$, cell viability was investigated by adding $0.8 \mathrm{mg} \mathrm{mL}^{-1}$ of 3-[4,5-dimethylthiazol-2-yl]-2,5 diphenyl tetrazolium bromide (MTT) (Sigma-Aldrich) to the media. After $3 \mathrm{~h}$, the supernatant was removed and the pellet of salt crystals was solubilized with $100 \mu \mathrm{L}$ well ${ }^{-1}$ of DMSO. The absorbance of the sample against a background control was measured at $570 \mathrm{~nm}$ using an ELISA reader microliter plate (BioTek Instruments, Winooski, VT).

\section{Acute oral toxicity in rats}

Female Wistar rats, weighting 250-300 g, were used for the acute toxicity studies. After the habituation period, animals were single housed and kept in a $12 \mathrm{~h}$ light dark ${ }^{-1}$ cycle at constant temperature $\left(20-22{ }^{\circ} \mathrm{C}\right.$ ) and humidity $\left(45-55^{\circ}\right)$, with food and water ad libitum. Animals were treated in accordance with the guidelines of the European Community Council Directive for Care and Use of Laboratory Animals. Acute toxicity was evaluated according to the methods described in OECD 425 main test guidelines with an upand-down procedure (UDP) (OECD 2008). Seven female Wistar rats were fasted overnight prior to treatment and subsequently administered with fixed doses of the EO (175, 550 and $2000 \mathrm{mg} \mathrm{kg}^{-1}$ ). The doses of the C. acaulis EO were prepared by dissolving the oil in $2 \%$ Tween 80 vehicle. Administration was carried out by gavage. The first animal was given a $175 \mathrm{mg} \mathrm{kg}^{-1}$ dose of the $C$. acaulis EO. When the animal survived after $48 \mathrm{~h}$, the next dose of $550 \mathrm{mg} \mathrm{kg}^{-1}$ was given to the second animal; when the second animal survived after $48 \mathrm{~h}$, the next animal was given a dose of
$2000 \mathrm{mg} \mathrm{kg}^{-1}$; when the third animal died within $48 \mathrm{~h}$, the $550 \mathrm{mg} \mathrm{kg}^{-1}$ dose was repeated; when the fourth animal survived within $48 \mathrm{~h}$, the $2000 \mathrm{mg} \mathrm{kg}^{-1}$ dose was repeated; when the fifth animal died within $48 \mathrm{~h}$, the $550 \mathrm{mg} \mathrm{kg}^{-1}$ dose was repeated; when the sixth animal survived within $48 \mathrm{~h}$, the $2000 \mathrm{mg} \mathrm{kg}^{-1}$ dose was repeated. Finally, a $2000 \mathrm{mg} \mathrm{kg}^{-1}$ dose was administered to the seventh rat that died within $48 \mathrm{~h}$. According to OECD 425 main test guidelines, the test was stopped since 5 reversal (response followed by nonresponse or vice versa) were observed. The animals were observed individually after dosing for signs of toxicity during the first $30 \mathrm{~min}$, periodically during the first $48 \mathrm{~h}$. The surviving animals were observed daily thereafter for a total of 14 days. Observations centered on the assessment of death and time of occurrence and signs of toxicity. In particular, activities of the central and autonomic nervous system (tremors, convulsions, straub, sedation, anaesthesia and ataxia, coma, lacrimation, cyanosis, ptosis, salivation and piloerection) were observed. The $\mathrm{LD}_{50}$ of $\mathrm{ME}$ (M1) was determined by limit test at $5000 \mathrm{mg} \mathrm{kg}^{-1}$ according to OECD 425 guidelines. A first animal received a dose of $5000 \mathrm{mg} \mathrm{kg}^{-1}$ by gavage. When the animal survived after $48 \mathrm{~h}$, two additional animals were dosed. Both animals survived after $48 \mathrm{~h}$ and the test was terminated. The microemulsion vehicle $\left(C_{\mathrm{M}}\right)$ was also administered to one rat and no evident sign of toxicity was observed.

\section{Statistical analysis}

In mosquito larvicidal tests, if control mortality reached 1-20\%, Abbott's formula was used (Abbott 1925). Probit analysis of dose-mortality data was conducted to estimate the $\mathrm{LC}_{16}, \mathrm{LC}_{30}, \mathrm{LC}_{50}$ and $\mathrm{LC}_{90}$ values and associated $95 \%$ confidence limits for each treatment (Finney 1971). Concerning experiments investigating the sublethal toxicity of $\mathrm{M} 1$ and $C$. acaulis EO, tested at different $\mathrm{LC}$ (i.e. $\mathrm{LC}_{16}$, $\mathrm{LC}_{30}, \mathrm{LC}_{50}$ and $\mathrm{LC}_{90}$ ) and exposure times, on $C x$. quinquefasciatus larval and pupal mortality (\%), as well as on adult emergence (\%), the data $(\%)$ were transformed by arcsine $\sqrt{ }$ and analysed by ANOVA followed by Tukey's HSD test $(P \leq 0.05)$. Rat mortality data were analysed by 'Acute Oral Toxicity (Guidelines 425) Statistical Program' (AOT425StatPgm) that computes $\mathrm{LD}_{50}$ and confidence interval through a maximum likelihood approach.

\section{Results and discussion}

\section{Chemical analysis of the essential oil obtained from $C$. acaulis roots}

Using GC-MS analysis, the EO obtained from the roots of C. acaulis (Fig. 1) has been characterized and its chemical 
Table 2 Composition (\%) of the Carlina acaulis EO-based microemulsions formulated in the initial screening

\begin{tabular}{llllll}
\hline Sample & $\begin{array}{l}\text { Polysorbate } \\
80\end{array}$ & $\begin{array}{l}\text { Alco- } \\
\text { holic } \\
\text { phase* }\end{array}$ & Ethyl oleate & $\begin{array}{l}\text { C. acaulis } \\
\text { EO }\end{array}$ & $\mathrm{H}_{2} \mathrm{O}$ \\
\hline S1 & 13 & 35 & - & 1.5 & 50.5 \\
S2 & 13 & 35 & 1 & 0.5 & 50.5 \\
S3 & 13 & 35 & 1.1 & 0.4 & 50.5 \\
S4 & 13 & 35 & 1.2 & 0.3 & 50.5 \\
S5 & 13 & 35 & 1.3 & 0.2 & 50.5 \\
S6 & 13 & 35 & 0.5 & 0.5 & 51 \\
S7 (M1) & 13 & 35 & - & 0.5 & 51.5 \\
S8 & 15 & 35 & - & 1.5 & 48.5 \\
S9 & 15 & 35 & 1 & 0.5 & 48.5 \\
S10 & 15 & 35 & 0.5 & 0.5 & 49 \\
S11 & 15 & 35 & - & 0.5 & 49.5 \\
\hline
\end{tabular}

*The alcoholic phase is composed of $30 \%$ glycerol and 5\% ethanol $96 \%$

components have been determined, with carlina oxide as the main constituent $(\sim 94 \%)$ according to the data reported in the literature (Benelli et al. 2019b). The analysis of carlina oxide by H-NMR and 2D NMR experiments was also linear with the data reported in the literature (Benelli et al. 2019b; Pavela et al. 2020a, b). Other minor components identified in the EO were benzaldehyde (3.1\%) and ar-curcumene $(0.4 \%)$.

\section{Preparation and characterization of the micro- and nanoemulsions}

The quali-quantitative composition of MEs was determined through an initial screening carried out on 11 formulations, in which the amount (\%) of the C. acaulis EO, the total oily phase and the surfactant were screened (Table 2). Samples were monitored for a period of about 1 month. At the end of this period, the most thermodynamically stable MEs seemed to be S4, S5 and S7 (data not shown). The last (S7) was selected because it was able to encapsulate the highest amounts of the active ingredient $(0.5 \% \mathrm{w} / \mathrm{w})$, with respect to the samples S4 and S5 (0.3 and $0.2 \%$, respectively). Thus, the $\mathrm{S} 7$ sample was renamed M1. Although previous studies reported the ability of EO-based MEs to encapsulate higher amount of the oil phase in systems having the same composition (Pavela et al. 2019b, c), in this specific case, the loading of $0.5 \% \mathrm{w} / \mathrm{w}$ of active ingredient could be explained by the fact that the ME formation depends not only on the type and amount of surfactants and co-surfactants, but also on the physico-chemical properties of the oil phase (McClements and Rao 2011). This aspect is more pronounced in the presence of EOs, that are not pure compounds but rather a complex mixture of different components (Pavela 2015).

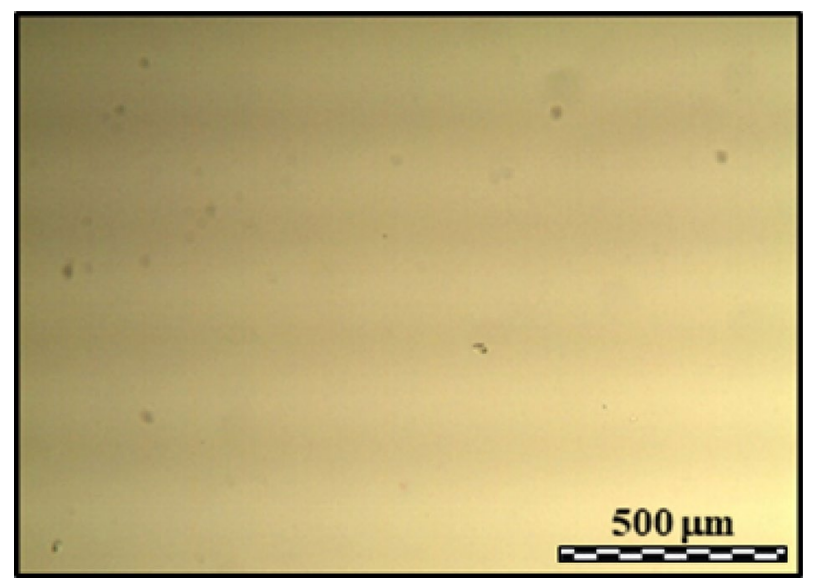

Fig. 2 Optical microscope image of microemulsion M1 containing $0.5 \%$ of $C$. acaulis essential oil

M1 was firstly characterized through optical microscopy and then through DLS analysis, to investigate the size of the dispersed phase. Figure 2 shows the presence of an isotropic system, confirming the real formation of a microemulsified sample (McClements 2012). The absence of visible oil droplets on the microscopy image meant that they had nanometric dimensions not detectable by optical microscope. The nanometric size range of the M1 dispersed phase was confirmed by DLS analysis (Fig. 3, black line). M1 showed a bimodal size distribution centred at $37.84 \mathrm{~nm}$ (80\%) and $408 \mathrm{~nm}(20 \%)$. The fraction of the populations with the smaller droplet size was predominant. The presence of a second particle population with a larger diameter in the intensity plot corresponds to a marginal fraction of the whole population. In fact, the intensity of the scattered light is proportional to the power of six of the particle diameters.

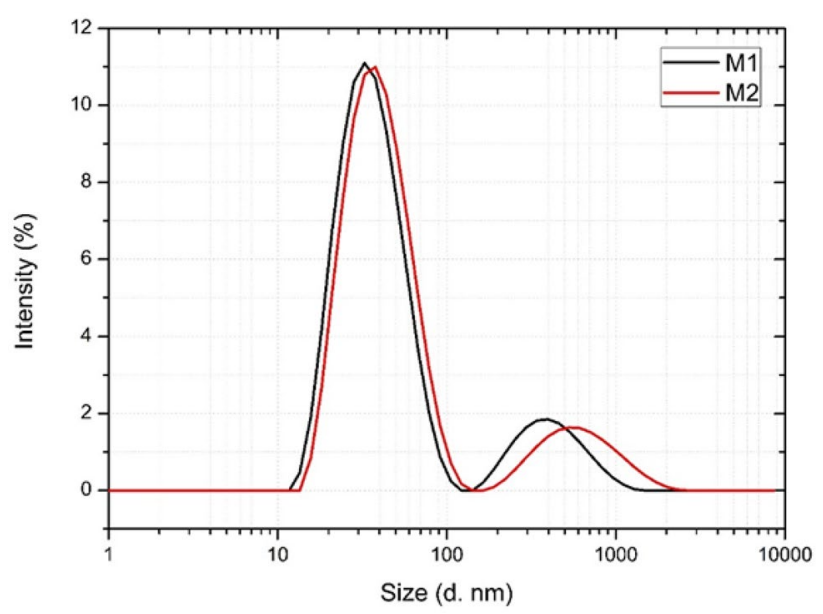

Fig. 3 Dynamic light scattering (DLS) traces of microemulsions M1 (black line) and M2 (red line), containing $0.5 \%$ of C. acaulis essential oil and $0.5 \%$ of pure carlina oxide, respectively 
Fig. 4 Dynamic light scattering (DLS) traces of microemulsions M1 (A) and M2 (B), containing $0.5 \%$ of $C$. acaulis essential oil and $0.5 \%$ of pure carlina oxide, respectively, at different time points: 0 day (t0), 1 month (t1), 3 months (t3), 6 months (t6)

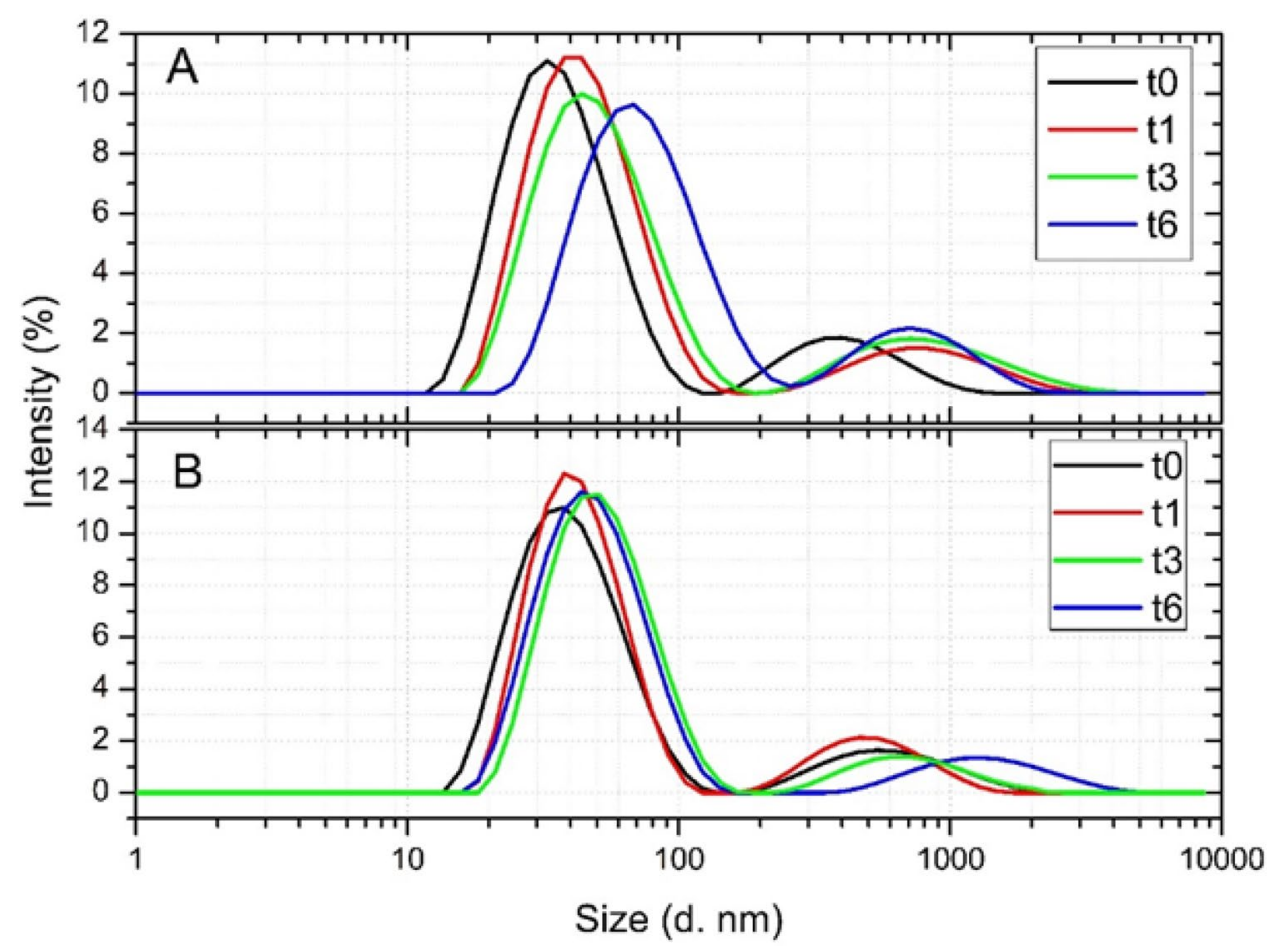

Therefore, only a small number of particles possessed a size over $100 \mathrm{~nm}$. This was confirmed by the DLS volume plot, which showed only one population having a medium droplet diameter centred around $30 \mathrm{~nm}$ (100\%) (data not shown).

Based on these results, a ME containing carlina oxide was formulated at the same conditions (sample M2). It reported the same quali-quantitative composition of M1, except the active ingredient, i.e. the $C$. acaulis EO was replaced by the purified carlina oxide. Also in this case the optical microscope image and the DLS trace confirmed the formation of a microemulsified system. As shown for M1, sample M2 showed a bimodal distribution in which the two populations had a medium diameter of $41.92 \mathrm{~nm}(85 \%)$ and $666 \mathrm{~nm}$ (15\%) (Fig. 3, red line). Interestingly, both samples showed the same size distribution trend, independently from the active ingredient. The physico-chemical stability of the samples was monitored after their storage at room temperature for up to six months. In particular, they were analysed by DLS at different time points: 0 day (t0), 1 month (t1), 3 months (t3) and 6 months (t6) (Fig. 4). Figure 4A shows a slight increase in the size of the dispersed phase of M1. This is more evident in the main droplets population, that, however, maintained the diameter centred below $100 \mathrm{~nm}$. As regarding sample $\mathrm{M} 2$, no remarkable differences in terms of hydrodynamic diameter were detected during the six months, except for a slight shifting of the smaller population towards higher values at $\mathrm{t} 6$ (Fig. $4 \mathrm{~b}$, blue line). Thus, M1 and M2 proved to be a thermodynamically stable system for up to six months.

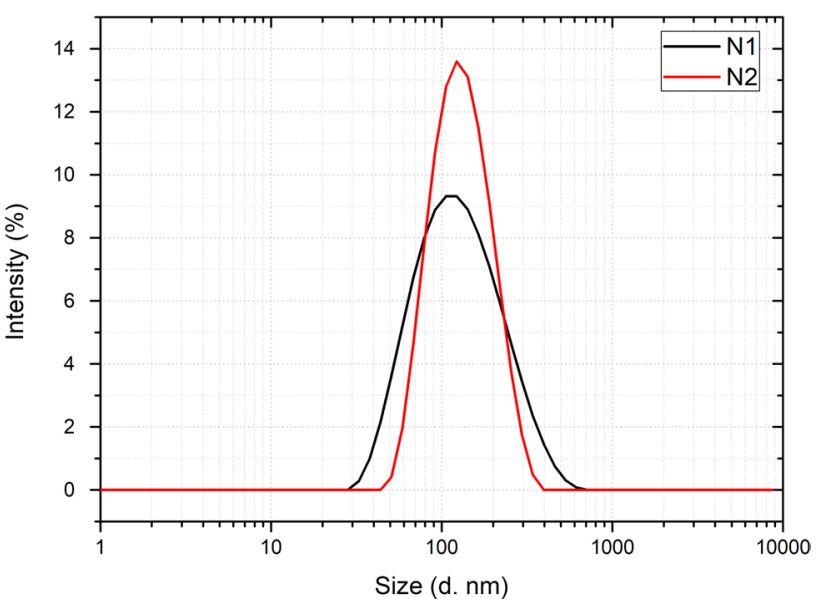

Fig. 5 Dynamic light scattering (DLS) traces of nanoemulsions N1 (black line) and N2 (red line), containing $0.5 \%$ of $C$. acaulis essential oil and $0.5 \%$ of pure carlina oxide, respectively

Carlina acaulis EO and carlina oxide-based NEs were formulated as well, to evaluate the influence of the encapsulation method on the biological activity of the active ingredients. NEs, relative to MEs, have a lower SOR (Pavoni et al. 2019b). It means that the oil phase (that in the case of EOs is the active ingredient) can be encapsulated, requiring a lower amount of surfactant. Thus, NEs could be considered a greener substitute for MEs since surfactants are potentially hazardous for the environment (Wilhelm et al. 1993). For the 
achievement of NEs, the procedure previously described was used. Although NEs are able to encapsulate higher amount of the oil phase than MEs, samples containing $0.5 \%(\mathrm{w} / \mathrm{w}$ ) of the active ingredient were formulated ( $\mathrm{N} 1$ and $\mathrm{N} 2$ ), in order to make a comparison between the biological activity of $C$. acaulis EO and carlina oxide-based MEs and NEs. Noticeably, they were achieved by using only $0.33 \%(w / w)$ of surfactant (Table 1).

Both NEs, N1 and N2 showed a monomodal size distribution centred between 140 and $145 \mathrm{~nm}$ (Fig. 5). Concerning such nanosystems, their physico-chemical properties depend on the quali-quantitative composition of the systems, as for MEs, but rather on the energetic input and the operating conditions (Mason et al. 2006).

The monomodal distribution of N1 and N2 traces was corroborated by the PDI (Polydispersity Index) values, an indicator (ranging from 0 to 1 ) of the quality of the system concerning the size distribution. The smaller is this index $(<0.25)$, the more monodispersed will be the system (Sadeghi et al. 2015).

The PDI values of NEs, N1 and N2, measured by DLS, were found to be 0.2 and 0.18 , respectively. These values were lower than those recorded for the corresponding MEs, M1 and M2 (0.33 and 0.32, respectively), proving that this latter system showed a bimodal size distribution of the dispersed phase.

Both N1 and N2 showed good stability at room temperature for a storage period of six months. The mean hydrodynamic diameter of the $\mathrm{N} 1$ and $\mathrm{N} 2$ oil droplets remained almost unchanged, confirming the thermodynamic stability of these systems (Fig. 6a and b).

From the technological point of view, MEs and NEs showed similarities and differences. The size of the dispersed phase of both formulations fell below $200 \mathrm{~nm}$, which is the limit established by some authors for the definition of a nanosystem (Huang et al. 2010). However, MEs showed smaller droplet size respect to NEs, and this is in line with the literature (McClements 2012). This was the reason behind their different macroscopic aspects, being MEs translucent while NEs form milky systems. In fact, the appearance of a colloidal dispersion tends to become translucent or transparent when the particle radius falls below $30 \mathrm{~nm}$ (Wooster et al. 2008). Furthermore, they differ for the preparation methods and the composition. Concerning the first aspect, MEs form spontaneously while NEs require external energy input to exceed the energetic gap between the two separated phases and the final colloidal system. Regarding the composition, MEs showed limitation in the amount of encapsulated oil phase, contrary to NEs. This latter, in fact, allowed the encapsulation of a higher amount of oil in the presence of a lower amount of surfactant (Pavoni et al. 2019b).

\section{Acute toxicity on Cx. quinquefasciatus}

Lethal concentrations estimated for the MEs and NEs, the EO and carlina oxide are shown in Table 3. The mortality of Cx. quinquefasciatus larvae was evaluated as acute toxicity manifested $24 \mathrm{~h}$ post-application. Results showed that the
Fig. 6 Dynamic light scattering (DLS) traces of nanoemulsions $\mathrm{N} 1$ (A) and $\mathrm{N} 2$ (B), containing $0.5 \%$ of C. acaulis essential oil and $0.5 \%$ of pure carlina oxide, respectively, at different time points: 0 day ( $\mathrm{t} 0), 1$ month ( $\mathrm{t} 1)$, 3 months (t3), 6 months (t6)

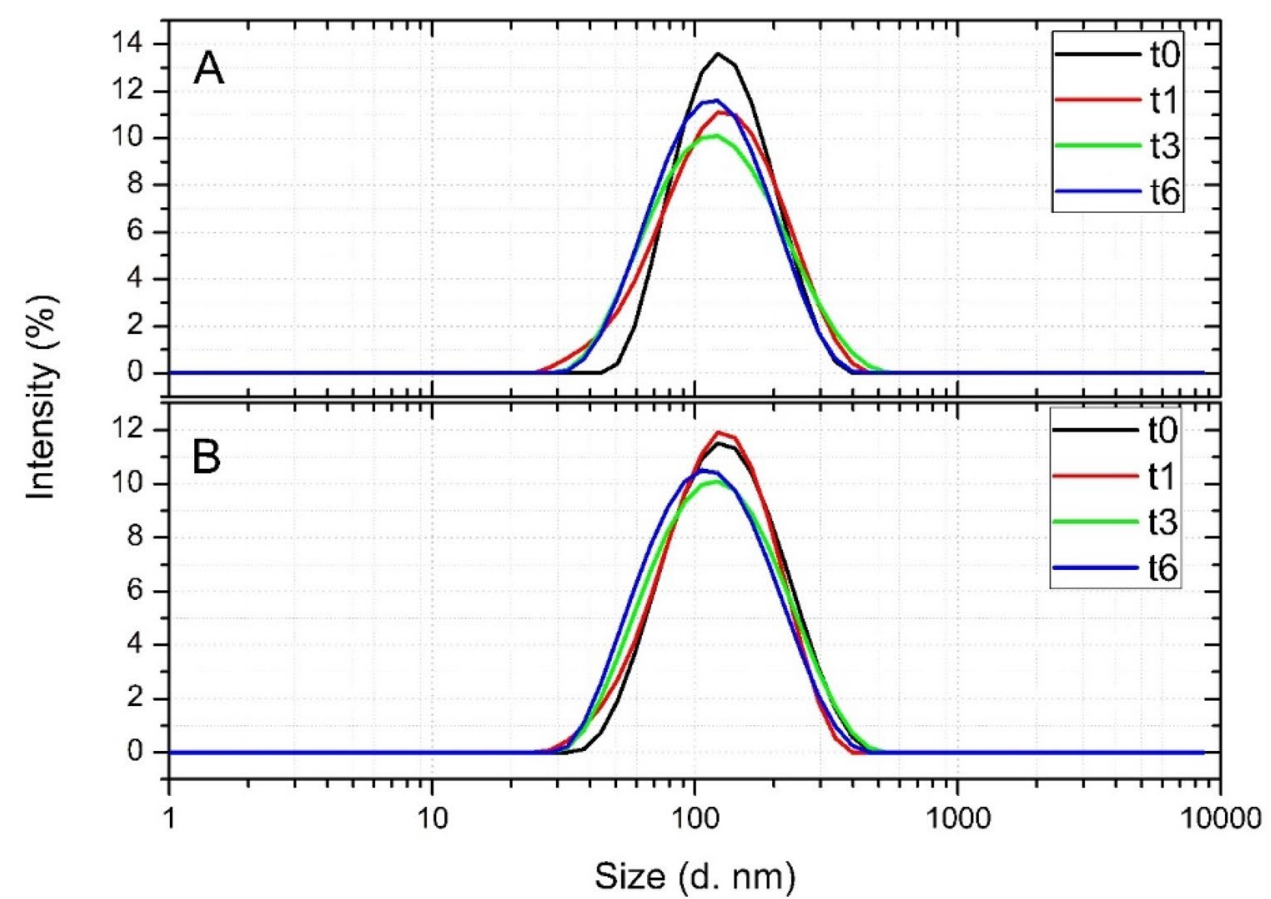




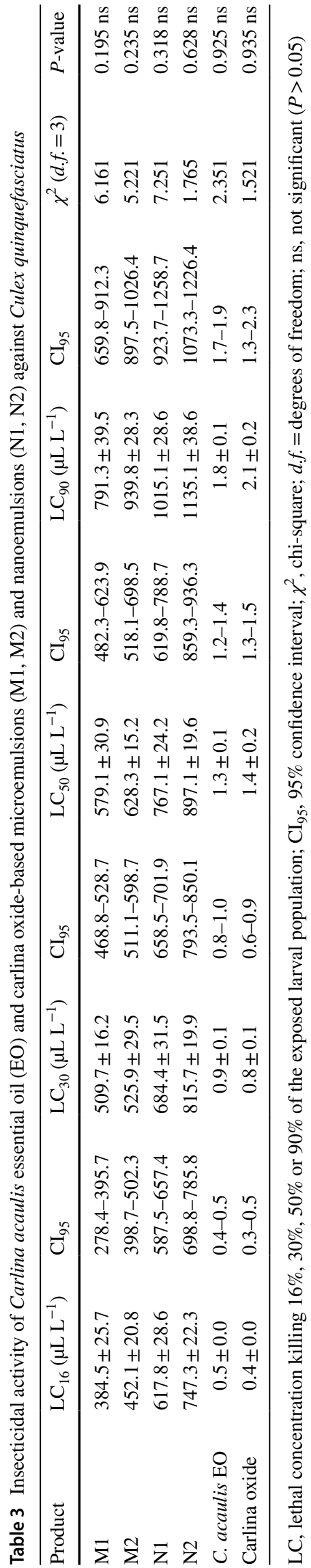

efficacy of the active ingredients was dependent on the kind of formulation in which they were encapsulated. The ME M1 was selected as the most efficient based on the comparison of lethal concentrations $\left[\mathrm{LC}_{50(90)}=579.1(791.3) \mu \mathrm{L} \mathrm{L}^{-1}\right.$, corresponding approximately to the equivalent of 2.3 (3.9) $\mu \mathrm{L} \mathrm{L}^{-1} \mathrm{EO}$, as the active ingredient], containing $13 \%$ polysorbate 80 and $35 \%$ alcoholic phase. M2 was slightly less efficient $\left[\mathrm{LC}_{50(90)}=628.3(939.8) \mu \mathrm{L} \mathrm{L}^{-1}\right.$, corresponding approximately to the equivalent of $3.1(4.7) \mu \mathrm{L} \mathrm{L}^{-1}$ carlina oxide, as the active ingredient]. However, the difference between M1 and M2 was not significant. In the present study, $\mathrm{LC}_{50}$ for the $\mathrm{EO}$ and carlina oxide was also estimated as 1.3 and $1.4 \mu \mathrm{L} \mathrm{L}^{-1}$, respectively (Table 3 ). The nanoemulsion $\mathrm{N} 2$ provided the least efficacy $\left[\mathrm{LC}_{50(90)}=897.1\right.$ $(1,135.1) \mu \mathrm{L} \mathrm{L}^{-1}$, corresponding approximately to the equivalent of 4.5 (5.7) $\mu \mathrm{L} \mathrm{L}^{-1} \mathrm{EO}$, as the active ingredient]; although containing the same amount of the EO as M1, N2 contained only $0.33 \%$ polysorbate 80 and no alcoholic phase.

The higher larvicidal efficacy of MEs, in particular M1, relative to NEs could be ascribed to their different particle sizes. In particular, MEs showed a droplet mean diameter of around $40 \mathrm{~nm}$, while NEs of around $140 \mathrm{~nm}$. The droplets size-mortality relationship has been also reported by Anjali et al. (2012), for the larvicidal activity of neem oil nanosystems against $C x$. quinquefasciatus. They observed that the neem oil-based nanosystem, with a medium diameter of $31 \mathrm{~nm}$, caused a higher larval mortality over those with a mean diameter of 93 and $251 \mathrm{~nm}$. Thus, $\mathrm{LC}_{50(90)}$ values decrease as the droplets size decreases. Specifically, the smaller EO droplets of MEs could allow a deeper penetration of the active ingredient into mosquito larvae.

\section{Sublethal effects of the most effective larvicide on $C x$. quinquefasciatus}

In terms of implementation of our research results in practice, we believe that the application of ME and NE, as well as of the EO or its main constituent carlina oxide, as an active ingredient of potential larvicides against $C x$. quinquefasciatus will not always provide uniform distribution of the active ingredient in water (Chalifour and Delfour 1992; Pavoni et al. 2019b), and thus that the larvae will not be exposed to concentrations corresponding to values $\geq \mathrm{LC}_{90}$ for at least $24 \mathrm{~h}$. Therefore, we focused on the effects of lethal and sublethal concentrations and various exposure times of the larvae for the most efficient $\mathrm{ME}$, i.e. M1, and the $C$. acaulis $\mathrm{EO}$.

Our results about the influence of exposure time of different $\mathrm{M} 1$ and $\mathrm{EO}$ lethal concentrations (i.e. $\mathrm{LC}_{16}, \mathrm{LC}_{30}$, $\mathrm{LC}_{50}$ and $\mathrm{LC}_{90}$ ) on larval and pupal mortality and on the percentage of emerged adults are presented in Tables 4 and 5. M1 provided the most significant effect on larval mortality 


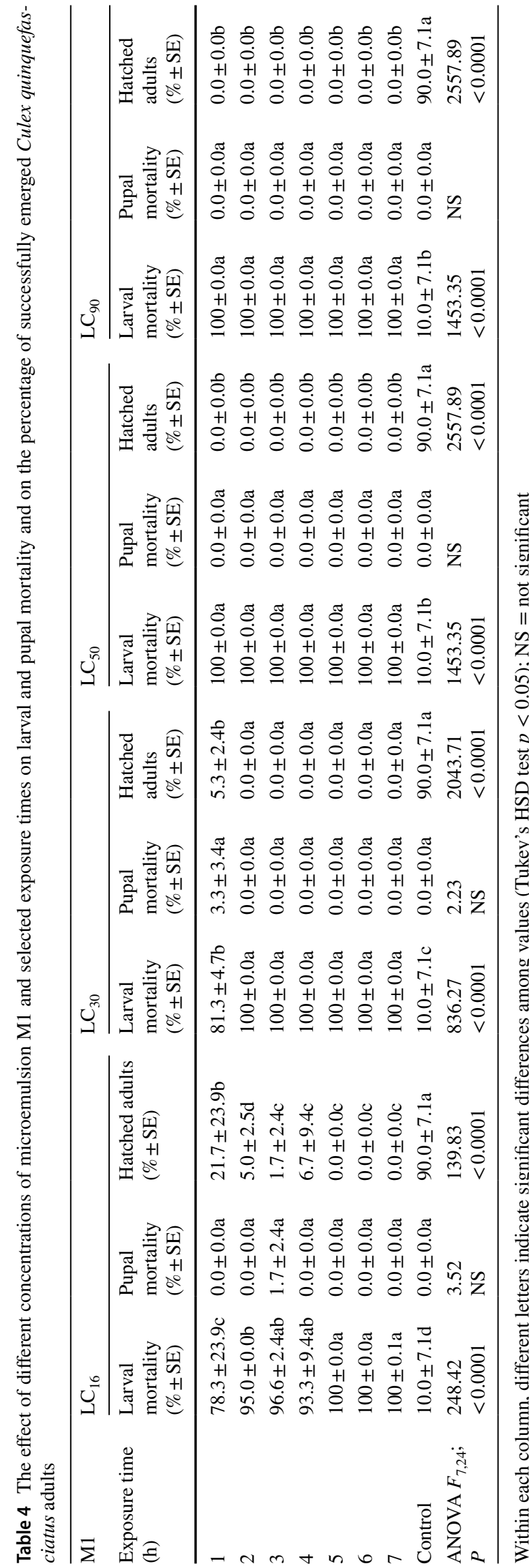

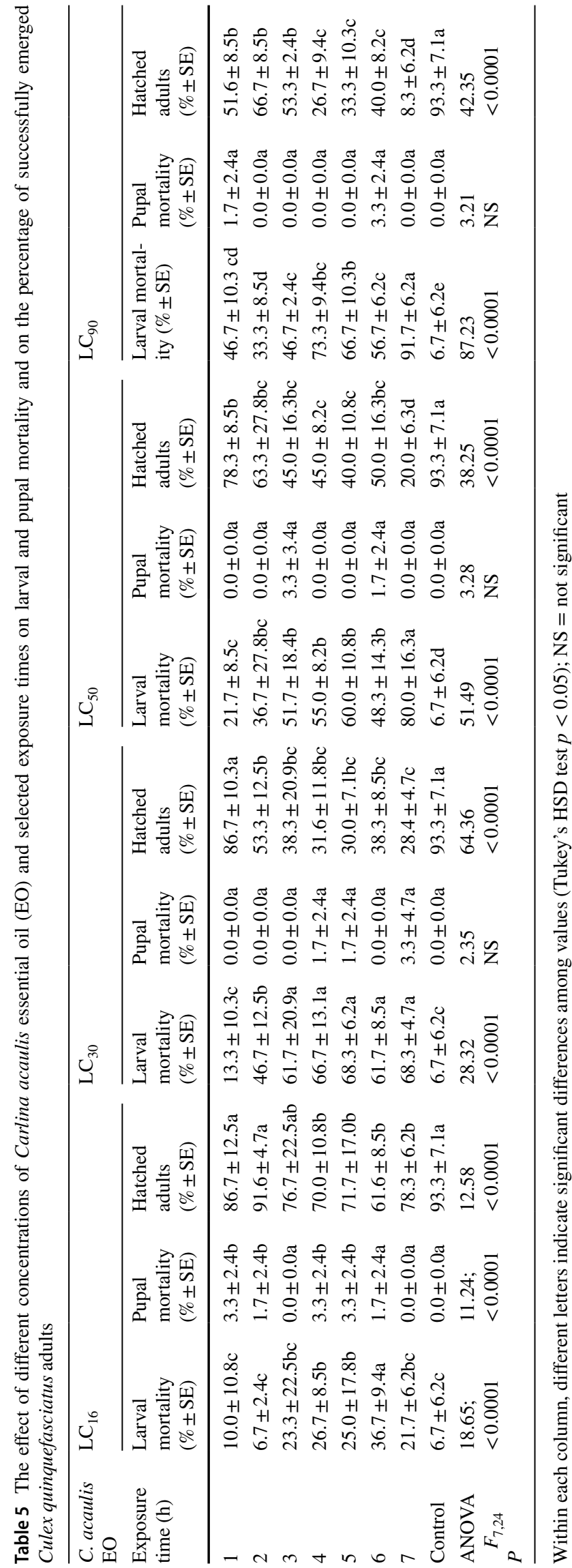


(Table 4) compared to the $\mathrm{EO}$ (Table 5). $\mathrm{LC}_{16}\left(384.5 \mu \mathrm{L} \mathrm{L}^{-1}\right.$, corresponding approximately to the equivalent of $1.9 \mu \mathrm{L} \mathrm{L}^{-1}$
EO, as the active ingredient) caused more than $78 \%$ mortality of the larvae after the exposure time of $1 \mathrm{~h}$, and fatal
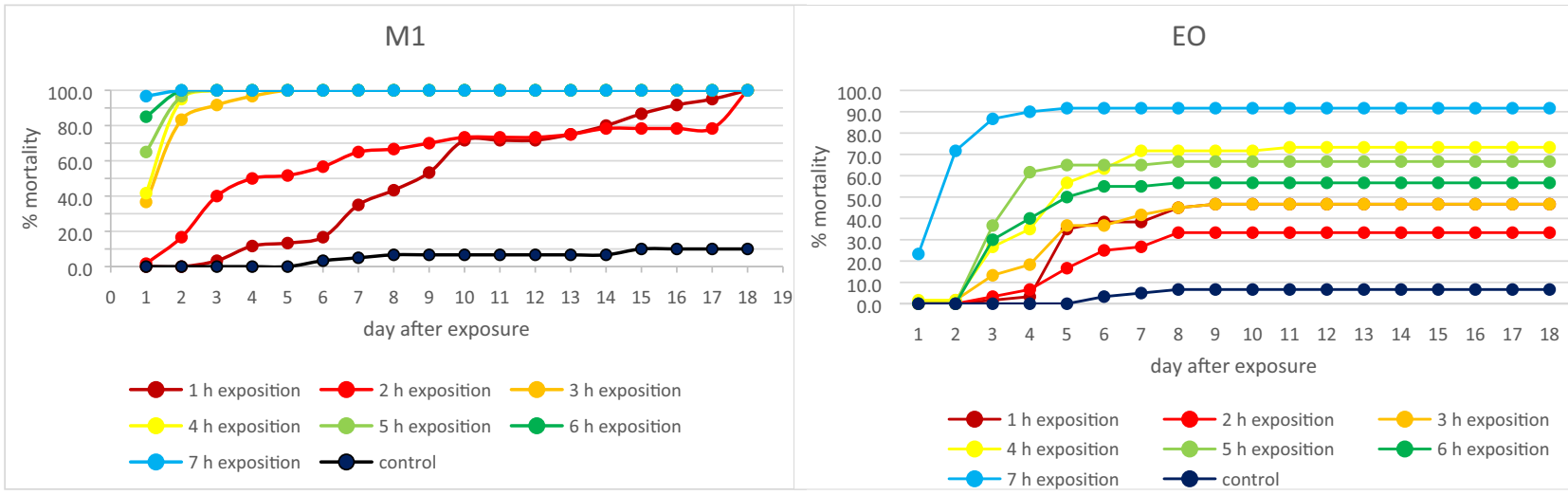

Fig. 7 Mortality over time of Culex quinquefasciatus larvae after exposure to Carlina acaulis essential oil microemulsion (M1) and C. acaulis essential oil (EO) concentrations corresponding to $\mathrm{LC}_{90}$
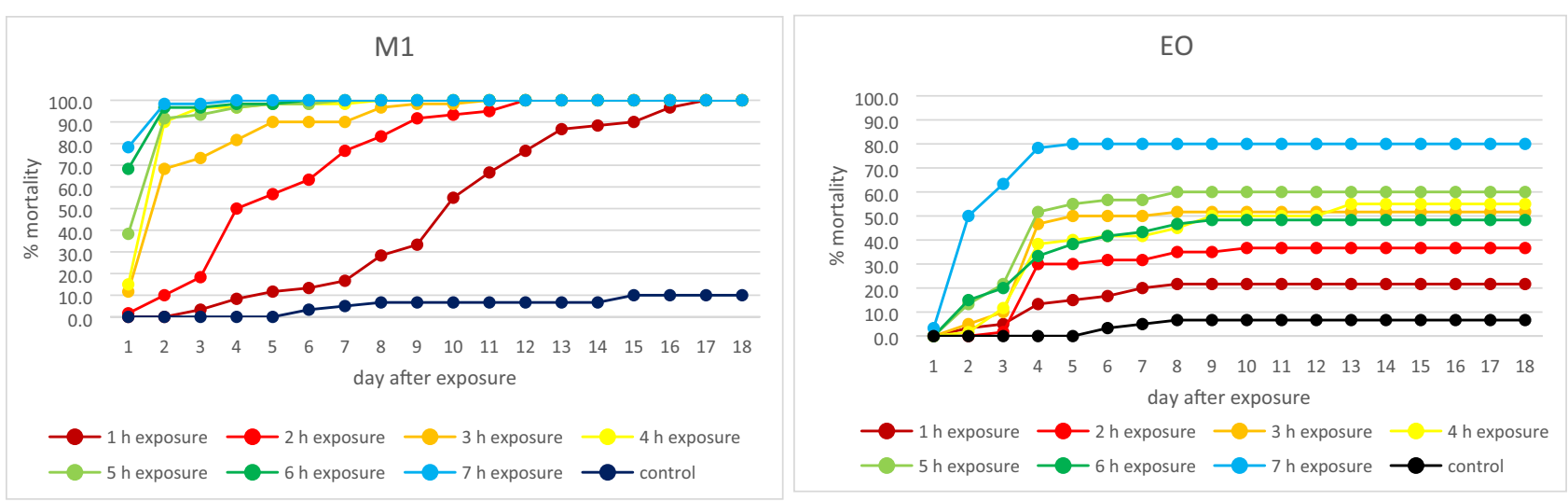

Fig. 8 Mortality over time of Culex quinquefasciatus larvae after exposure to Carlina acaulis essential oil microemulsion (M1) and C. acaulis essential oil (EO) concentrations corresponding to $\mathrm{LC}_{50}$
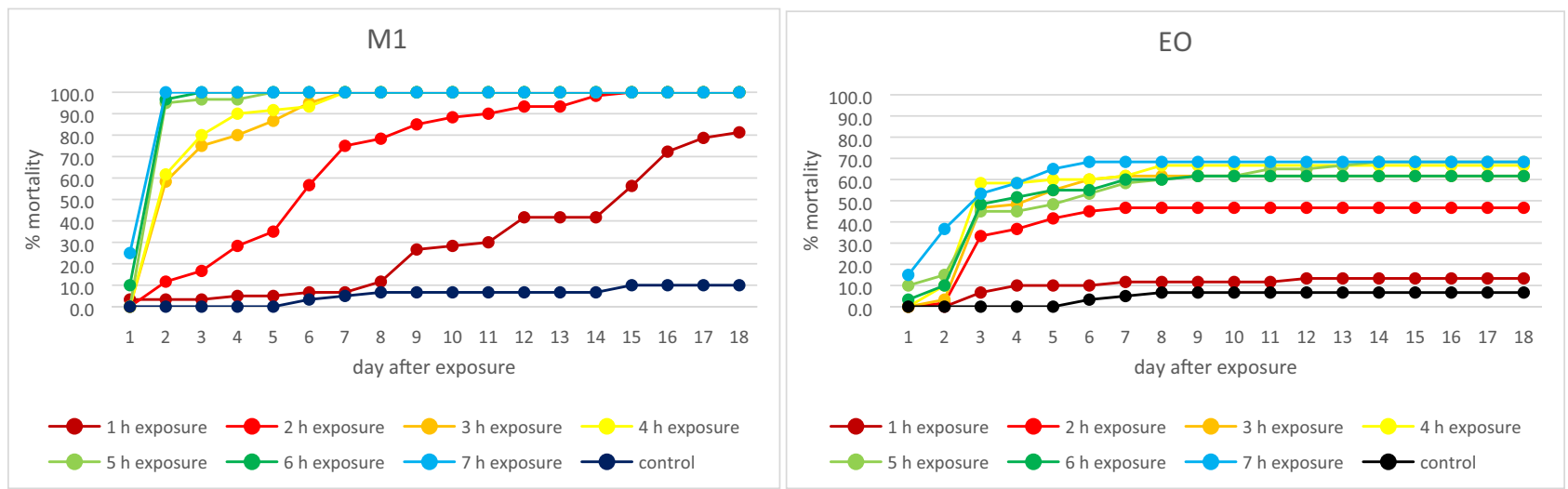

Fig. 9 Mortality over time of Culex quinquefasciatus larvae after exposure to Carlina acaulis essential oil microemulsion (M1) and C. acaulis essential oil (EO) concentrations corresponding to $\mathrm{LC}_{30}$ 


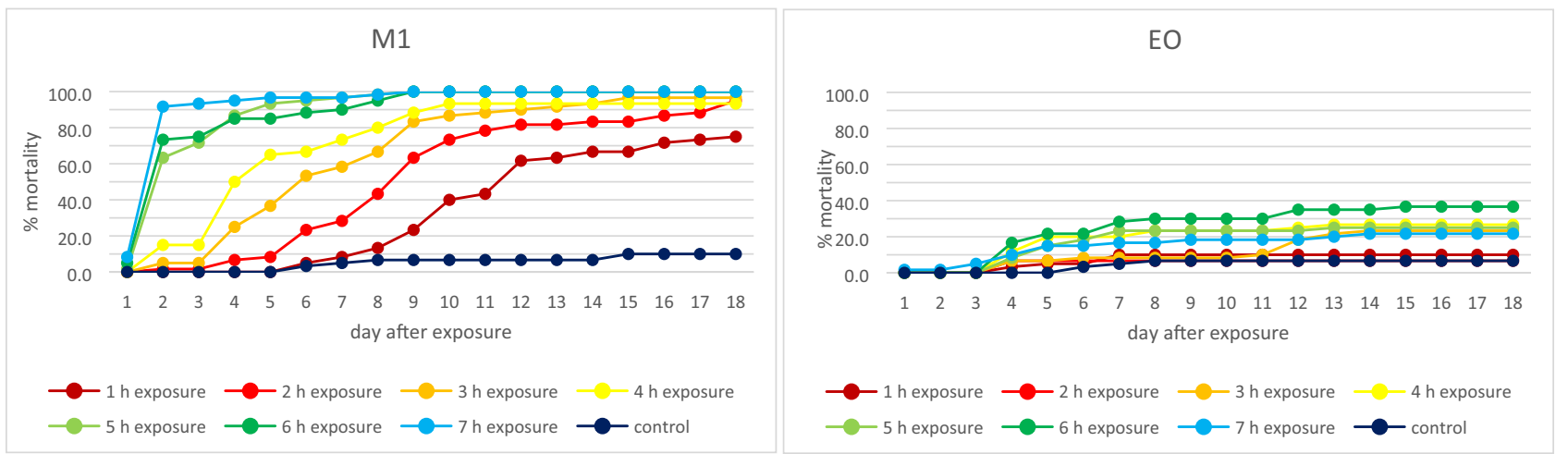

Fig. 10 Mortality over time of Culex quinquefasciatus larvae after exposure to Carlina acaulis essential oil microemulsion (M1) and C. acaulis essential oil (EO) concentrations corresponding to $\mathrm{LC}_{16}$

effects were observed when the larvae were exposed to this $\mathrm{ME}$ for $5 \mathrm{~h}$ and more. With the larvae exposed to $\mathrm{LC}_{30}, 100 \%$ mortality was observed as early as after the exposure time of $2 \mathrm{~h}$, and larval exposure to concentrations of this ME corresponding to $\mathrm{LC}_{50}$ and higher had fatal consequences for the larvae as early as after 1 -h exposure.

Nevertheless, this phenomenon was not observed after application of the EO, although this was an active ingredient in the ME M1 (Table 5). As shown by the results, application of a low concentration corresponding to $\mathrm{LC}_{16}\left(0.5 \mu \mathrm{L} \mathrm{L}^{-1}\right)$ resulted in limited $C x$. quinquefasciatus mortality, ranging between 6.7 and $36.7 \%$, and the lethal concentration corresponding to $\mathrm{LC}_{90}\left(1.8 \mu \mathrm{L} \mathrm{L}^{-1}\right)$, equivalent approximately to $\mathrm{LC}_{16}$ estimated for M1, reached the highest mortality of $91.7 \%$ only after $7 \mathrm{~h}$ of exposure. Interestingly, no significant pupal mortality was observed compared to the control (Tables 4 and 5).

In order to better understand the difference between EO and ME efficacies, Figs. 7, 8, 9 and 10 illustrate the development of mean cumulative larval mortality over time for individual concentrations and various exposure times. Based on the comparison of cumulative mortality over time between M1 and the EO, while the EO shows an increase in mortality approximately for the first 7 days from termination of exposure, with only exceptional mortality afterwards, M1 shows an increase in mortality throughout the observation period, i.e. until the larvae become pupae (Figs. 7, 8, 9 and 10).

Our results thus indicate that M1 application, even at $\mathrm{LC}_{16}$, had fatal consequences for the $C x$. quinquefasciatus larvae, which was probably caused by a better water dispersion and penetration of the active ingredient through the larval cuticle or spiracles (Du et al. 2016). However, this hypothesis should be verified in further experiments. In the end, M1 did provide a significantly better efficacy compared to the EO and can be therefore considered as a prototype formulation that is more efficient than the emulsified EO alone.
We are also aware that further experiments will be needed, focusing on the effects of sublethal concentrations on subsequent fertility of adult $C x$. quinquefasciatus mosquitoes, because for example, for Musca domestica L. (Diptera: Muscidae) the exposure to EO from C. acaulis significantly reduced the natality of the surviving adults (Pavela et al. 2020b). Effects of EOs applied in sublethal doses or concentrations in terms of reduced fertility, fecundity and natality have also been found for other EOs (Benelli et al. 2018b), and therefore it is important to study this phenomenon further-not only for target, but also non-target organisms, given that currently, only superficial information is available regarding any effects of this EO or carlina oxide, e.g. on aquatic non-target organisms. The first report on the influence of carlina oxide and EO on non-target water organisms was brought by the work of Benelli et al. (2019b). Their non-target impact was evaluated through experiments on adults of the aquatic microcrustacean Daphnia magna Straus. Both showed significantly lower toxicity compared to cypermethrin.

\section{Dermal toxicity of $C$. acaulis essential oil and microemulsion}

Carlina acaulis EO and its ME (M1) were tested on two normal human cell lines, immortalized human keratinocytes cell line (HaCaT) and primary human fibroblast cell line (NHF A12). Cells were treated with different concentrations of the EO (from 1.69 to $863.74 \mu \mathrm{g} \mathrm{mL}^{-1}$ ) and ME (from 205.8 to $105,000 \mu \mathrm{g} \mathrm{mL}^{-1}$ ) for $24 \mathrm{~h}$. The results showed that $C$. acaulis EO induced a cytotoxic effect on both cell lines in a dose dependent manner, with an $\mathrm{IC}_{50}$ of $115.92 \pm 6.1 \mu \mathrm{g} \mathrm{mL}$ for NHF A12 cells and $88.31 \pm 1.3 \mu \mathrm{g} \mathrm{mL}^{-1}$ for HaCaT cells (Fig. 11). In contrast, $C$. acaulis EO ME (M1) treatment resulted in an $\mathrm{IC}_{50}$ of $5392.8 \pm 315 \mu \mathrm{g} \mathrm{mL}^{-1}$ for NHF A12 cells and $1457.4 \pm 63 \mu \mathrm{g} \mathrm{mL}{ }^{-1}$ for HaCaT cells, while the oil-free microemulsion, used as control $\left(C_{\mathrm{M}}\right)$, showed 
Fig. 11 C. acaulis essential oil (EO) cytotoxic effect. Cell viability $(\%)$ was determined in NHF A12 and HaCaT cell lines by MTT assay. Cells were treated for $24 \mathrm{~h}$ with different concentrations of EO. Data shown are expressed as mean \pm SE of three separate experiments. $* p<0.05$ versus Vhc
NHF A12

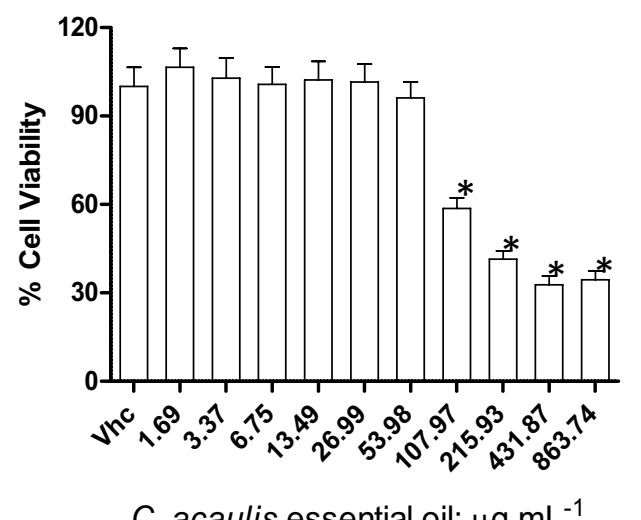

C. acaulis essential oil; $\mu \mathrm{g} \mathrm{mL}^{-1}$

$$
\text { EO IC }{ }_{50} 115.92 \pm 6.1 \mu \mathrm{g} \mathrm{mL}^{-1}
$$

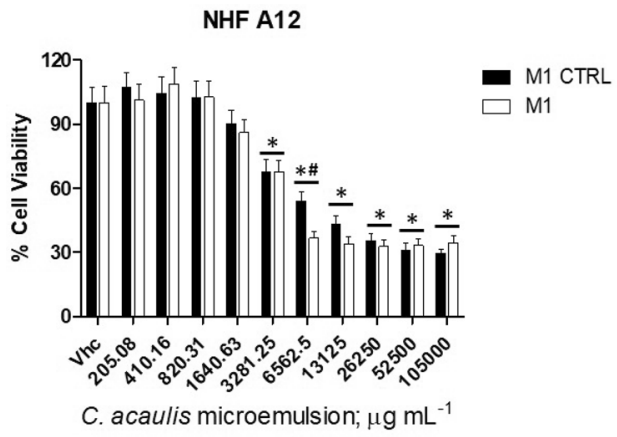

M1 IC $505392.8 \pm 315 \mu \mathrm{g} \mathrm{mL}^{-1}$ M1 CTRL IC $507068.6 \pm 357 \mu \mathrm{g} \mathrm{mL}^{-1}$
$\mathrm{HaCaT}$

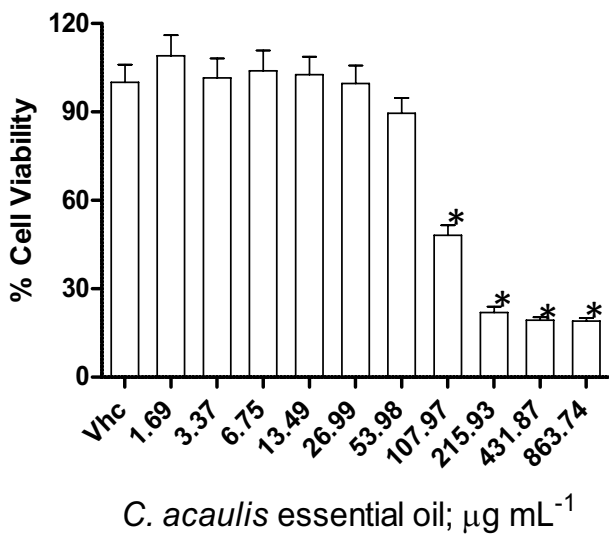

EO IC ${ }_{50} 88.31 \pm 1.3 \mu \mathrm{g} \mathrm{mL}^{-1}$

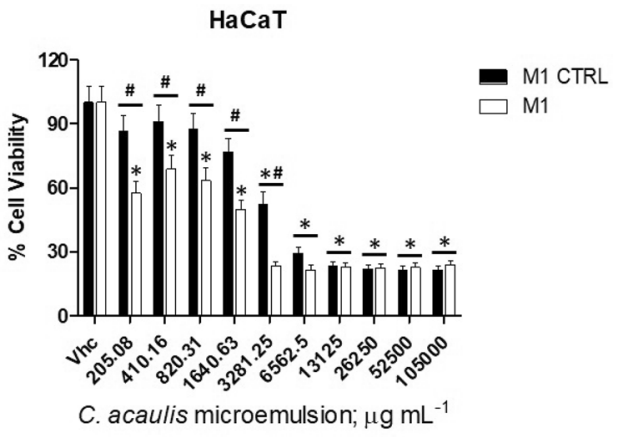

M1 IC ${ }_{50} 1457.4 \pm 63 \mu \mathrm{g} \mathrm{mL}^{-1}$ M1 CTRL IC $503361.05 \pm 105 \mu \mathrm{g} \mathrm{mL}^{-1}$ an $\mathrm{IC}_{50}$ of $7068.6 \pm 357 \mu \mathrm{g} \mathrm{mL} \mathrm{m}^{-1}$ for NHF A12 cells and $3361.05 \pm 105 \mu \mathrm{g} \mathrm{mL}^{-1}$ for HaCaT cells (Fig. 12). These results confirmed that the pure EO of $C$. acaulis showed a mild toxicity on the two cell lines and that this toxicity was negligible when the EO was encapsulated into the ME. Notably, the reduction of cell viability at $100 \mu \mathrm{g} \mathrm{mL}^{-1}$ of EO was $22.75 \%$ for NHF A12 and $34.51 \%$ for HaCaT cells; thus, this product cannot be considered cytotoxic according to the ISO guidelines (ISO 20093-5 2009). Our results were in contrast with those recently reported by Wnorowski et al. (2020) who tested carlina oxide, the main constituent of the $C$. acaulis $\mathrm{EO}$, in the concentration range of $3.125-50 \mu \mathrm{g} \mathrm{mL}^{-1}$, on $\mathrm{BJ}$ normal foreskin fibroblasts and found a concentrationdependent increase in necrotic effects. However, they neither determined the $\mathrm{IC}_{50}$ concentration on this cell line nor evaluated its rate of toxicity according to the ISO guidelines (ISO 20093-5 2009).

\section{Acute oral toxicity in rats}

The estimated $\mathrm{LD}_{50}$ of $C$. acaulis $\mathrm{EO}$ was $1098 \mathrm{mg} \mathrm{kg}^{-1}$, with an approximate $95 \%$ confidence interval of $550-2000 \mathrm{mg} \mathrm{kg}^{-1}$. The dose of $550 \mathrm{mg} \mathrm{kg}^{-1}$ did not cause any signs of toxicity in the rats, while for the $2000 \mathrm{mg} \mathrm{kg}^{-1}$ dose tremors, sedation, ataxia, ptosis and coma were progressively observed starting approximately $24 \mathrm{~h}$ after the administration.

These data fill the gap concerning the potential toxicity attributed to the use of $C$. acaulis EO (Hermann et al. 2011; Stojanović-Radić et al. 2012) and allow it to be classified as moderately toxic when compared with the EOs from several aromatic plants such as Melaleuca alternifolia (Maiden \& Betche) Cheel $\left(\mathrm{LD}_{50}=1900 \mathrm{mg} \mathrm{kg}^{-1}\right)$, Thymus vulgaris $\mathrm{L}$. $\left(\mathrm{LD}_{50}=2840 \mathrm{mg} \mathrm{kg}^{-1}\right)$, Foeniculum vulgare Mill. $\left(\mathrm{LD}_{50}=3120 \mathrm{mg} \mathrm{kg}^{-1}\right)$ and Zingiber officinale Roscoe $\left(\mathrm{LD}_{50}=3400 \mathrm{mg} \mathrm{kg}{ }^{-1}\right)$. Being a 'monocomponent' EO, the overall toxicity may be attributed to the polyacetylene, carlina oxide $(94 \%)$. In this regard, 
the $\mathrm{LD}_{50}$ obtained after oral administration was overlapping those of some EO constituents such as thymol $\left(\mathrm{LD}_{50}=980 \mathrm{mg} \mathrm{kg}^{-1}\right)$, dillapiol $\left(\mathrm{LD}_{50}=1000 \mathrm{mg} \mathrm{kg}^{-1}\right)$ and cinnamaldehyde $\left(\mathrm{LD}_{50}=1160 \mathrm{mg} \mathrm{kg}^{-1}\right.$ ) (Dev and Koul 1997; Isman and Machial 2006), and was significantly higher than that of $\alpha$-thujone $\left(\mathrm{LD}_{50}=45 \mathrm{mg} \mathrm{kg}^{-1}\right)$, pulegone $\left(\mathrm{LD}_{50}=150 \mathrm{mg} \mathrm{kg}{ }^{-1}\right)$ and thymoquinone $\left(\mathrm{LD}_{50}=794 \mathrm{mg} \mathrm{kg}^{-1}\right.$ ) (Al-Ali et al. 2008; Maggi and Benelli 2018). Our data confirmed that $C$. acaulis EO is relatively safe when given orally to rats. Thus, in the case the EO is encapsulated in MEs and NEs at $0.5 \%$ concentration, the possibility to fulfil the requirements of regulatory agencies for insecticidal formulations, in terms of maximum toxicity levels $\left(\mathrm{LD}_{50}>5000 \mathrm{mg} \mathrm{kg}^{-1}\right)$ (Isman and Machial, 2006), is highly likely. Indeed, the $\mathrm{LD}_{50}$ of ME M1 was greater than $5000 \mathrm{mg} \mathrm{kg}^{-1}$ and no adverse effect were observed after one week. Based on these results the $C$. acaulis EO ME was found to be safe, demonstrating no acute oral toxicity up to $5000 \mathrm{mg} \mathrm{kg}^{-1}$ in female Wistar rats.

Recently, the carlina oxide toxicity has been evaluated by Wnorowski et al. (2020) on zebrafish embryos. These authors found that the compound produced high acute toxicity with coagulation of embryos, showing a $\mathrm{LC}_{50}$ value of $10.13 \mu \mathrm{g} \mathrm{mL}^{-1}$, and affected the heart function in larvae. Likewise, the toxicity of C. acaulis EO and carlina oxide on human fibroblasts has been well documented (Pavela et al. 2020a, b; Wnorowski et al. 2020). On this basis, it is important to perform further tests to provide data on the chronic and sub-chronic toxicity, inhalation effects and immunotoxicity given by $C$. acaulis EO-based formulations on animals. Furthermore, the effects of these formulations on pollinators and natural enemies of target insects under field conditions should be explored in the future.

\section{Conclusions}

In the present study, a prototype formulation titrated in $0.5 \%$ of $C$. acaulis EO with high efficacy on larvae of $C x$. quinquefasciatus $\left(\mathrm{LC}_{50}=579.1 \mu \mathrm{L} \mathrm{L}^{-1}\right)$ was developed. Furthermore, sublethal toxicity experiments showed that the M1 application, even at $\mathrm{LC}_{16}$, led to $100 \%$ insecticidal efficacy for the whole period, at variance with the EO, which failed to show a long-lasting larvicidal action. Further research is still needed to understand the higher toxicity of $C$. acaulis ME over NE carrying the same active ingredients (i.e. $C$. acaulis $\mathrm{EO}$ and carlina oxide), as well as their precise mode of action on mosquito larvae.

From a toxicological standpoint, the $C$. acaulis EO and its encapsulated form (M1) were slightly toxic to human fibroblasts and keratinocytes. Furthermore, the EO appeared to be mildly toxic to rats, with $\mathrm{LD}_{50}$ overlapping those of other industrially important EO constituents such as thymol and cinnamaldehyde (Pavela and Benelli 2016). To fulfil the requirements of regulatory agencies and reach the marketing approval as a botanical insecticide, we determined also the $\mathrm{LD}_{50}$ of the encapsulated form of $C$. acaulis $\mathrm{EO}$ (ME) suggesting the safety of this prototype formulation $\left(\mathrm{LD}_{50}>5000 \mathrm{mg} \mathrm{kg}{ }^{-1}\right)$ to human health.

\section{Authors' contribution}

RoP, LP, FM and GB conceived and designed the study. All authors performed experiments and analysed the data. RoP, FM, LP and GB wrote the first draft of the manuscript. All authors reviewed, read and approved the final manuscript.

Acknowledgements R. Pavela would like to thank the Ministry of Agriculture of the Czech Republic for its financial support concerning botanical pesticide and basic substances research (Project MZERO0418). This work was also financially supported by the Italian MIUR fund (Grant 2017CBNCYT_005 to R.P.) and University of Camerino (Fondo di Ateneo per la Ricerca, FAR). The authors thank Prof. Irene Ricci, University of Camerino, for kindly providing the picture of Carlina acaulis that was included in Fig. 1.

Funding Open Access funding provided by Università di Pisa.

\section{Compliance with ethical standards}

Conflict of interest The authors declare no competing interests.

Open Access This article is licensed under a Creative Commons Attribution 4.0 International License, which permits use, sharing, adaptation, distribution and reproduction in any medium or format, as long as you give appropriate credit to the original author(s) and the source, provide a link to the Creative Commons licence, and indicate if changes were made. The images or other third party material in this article are included in the article's Creative Commons licence, unless indicated otherwise in a credit line to the material. If material is not included in the article's Creative Commons licence and your intended use is not permitted by statutory regulation or exceeds the permitted use, you will need to obtain permission directly from the copyright holder. To view a copy of this licence, visit http://creativecommons.org/licenses/by/4.0/.

\section{References}

Abbott WS (1925) A method of computing the effectiveness of an insecticide. J Econ Entomol 18:265-267

Al-Ali A, Alkhawajah AA, Randhawa MA, Shaikh NA (2008) Oral and intraperitoneal $\mathrm{LD}_{50}$ of thymoquinone, an active principle of Nigella sativa, in mice and rats. J Ayub Med Coll Abbottabad 20:25-27

Anjali CH, Sharma Y, Mukherjee A, Chandrasekaran N (2012) Neem oil (Azadirachta indica) nanoemulsion: a potent larvicidal agent against Culex quinquefasciatus. Pest Manag Sci 68:158-163

Anton N, Vandamme TF (2011) Nano-emulsions and micro-emulsions: clarifications of the critical differences. Pharm Res 28:978-985 
Benelli G, Pavela R (2018a) Beyond mosquitoes-essential oil toxicity and repellency against bloodsucking insects. Ind Crops Prod 117:382-392

Benelli G, Pavela R (2018b) Repellence of essential oils and selected compounds against ticks-a systematic review. Acta Trop 179:47-54

Benelli G, Rajeswary M, Govindarajan M (2018a) Towards green oviposition deterrents? Effectiveness of Syzygium lanceolatum (Myrtaceae) essential oil against six mosquito vectors and impact on four aquatic biological control agents. Environ Sci Pollut R 25:0218-10227

Benelli G, Pavela R, Giordani C, Casettari L, Curzi G, Cappellacci L, Petrelli R, Maggi F (2018b) Acute and sub-lethal toxicity of eight essential oils of commercial interest against the filariasis mosquito Culex quinquefasciatus and the housefly Musca domestica. Ind Crops Prod 112:668-680

Benelli G, Maggi F, Canale A, Mehlhorn H (2019a) Lyme disease is on the rise-How about tick repellents? a global view. Entomol General 39:61-72

Benelli G, Pavela R, Petrelli R, Nzekoued FK, Cappellacci L, Lupidi G, Quassinti L, Bramucci M, Sute S, Dall'Acqua S, Canale A, Maggi F (2019b) Carlina oxide from Carlina acaulis root essential oil acts as a potent mosquito larvicide. Ind Crop Prod 137:356-366

Benelli G, Pavela R, Zorzetto C, Sánchez-Mateo CC, Santini G, Canale A, Maggi F (2019c) Insecticidal activity of the essential oil from Schizogyne sericea (Asteraceae) on four insect pests and two nontarget species. Entomol Gen 39(1):9-18. https://doi.org/10.1127/ entomologia/2019/0662

Benelli G, Wilke ABB, Bloomquist JR, Desneux N, Beier JC (2021a) Overexposing mosquitoes to insecticides under global warming: a public health concern? Sci Total Environ. https://doi. org/10.1016/j.scitotenv.2020.143069

Benelli G, Rizzo R, Zeni V, Govigli A, Samková A, Sinacori M, Lo Verde G, Pavela R, Cappellacci L, Petrelli R, Spinozzi E, Morshedloo MR, Maggi F, Canale A (2021b) Carlina acaulis and Trachyspermum ammi essential oils formulated in protein baits are highly toxic and reduce aggressiveness in the medfly, Ceratitis capitata. Ind Crops Prod 161:113191. https://doi.org/10.1016/j. indcrop.2020.113191

Cappellani MR, Perinelli DR, Pescosolido L, Schoubben A, Cespi M, Cossi R, Blasi P (2018) Injectable nanoemulsions prepared by high pressure homogenization: processing, sterilization, and size evolution. Appl Nanosci 8:1483-1491

Cespi M, Quassinti L, Perinelli DR, Bramucci M, Iannarelli R, Papa F et al (2017) Microemulsions enhance the shelf-life and processability of Smyrnium olusatrum L. essential oil. Flavour Fragr J 32:159-164

Chaieb I, Zarrad K, Sellam R, Tayeb W, Hammouda AB, Laarif A, Bouhachem S (2018) Chemical composition and aphicidal potential of Citrus aurantium peel essential oils. Entomol General 37:63-75

Chalchat J-C, Đordević S, Gorunović M (1996) Composition of the essential oil from the root of Carlina acaulis L. Asteraceae $\mathrm{J}$ Essent Oil Res 8:577-578

Chellappandian M, Vasantha-Srinivasan P, Senthil-Nathan S, Karthi S, Thanigaivel A, Ponsankar A et al (2018) Botanical essential oils and uses as mosquitocides and repellents against dengue. Environ Int 113:214-223

Chalifour A, Delfour MC (1992) Optimal distribution of larvicide in running waters. SIAM J Optim 2(2):264-303

Committee for Veterinary Medicinal Products (1999) Committee for Veterinary Medicinal Products. EMEA/MRL/631/99-FINAL

Cousyn G, Dalfrà S, Scarpa B, Geelen J, Anton R, Serafini M, Delmulle L (2013) Project BELFRIT: harmonizing the use of plants in food supplements in the European Union: Belgium, France and Italy-a first step. Eur Food Feed Law Rev 8:187-196

Desneux N, Decourtye A, Delpuech JM (2007) The sublethal effects of pesticides on beneficial arthropods. Annu Rev Entomol 52:81-106

Dev S, Koul O (1997) Insecticides of natural origin. Harwood Academic Publishers, Amsterdam, Netherlands

Dordević S, Petrović S, Dobrić S, Milenković M, Vucićević D, Zizić S, Kukić J (2007) Antimicrobial, anti-inflammatory, anti-ulcer and antioxidant activities of Carlina acanthifolia root essential oil. J Ethnopharmacol 109:458-463

Du Z, Wang C, Tai X, Wang G, Liu X (2016) Optimization and characterization of biocompatible oil-in-water nanoemulsion for pesticide delivery. ACS Sustain Chem Eng 4(3):983-991

Finney DJ (1971) Probit analysis. Cambridge University Press, London

Govindarajan M, Rajeswary M, Benelli G (2016) Chemical composition, toxicity and non-target effects of Pinus kesiya essential oil: an eco-friendly and novel larvicide against malaria, dengue and lymphatic filariasis mosquito vectors. Ecotox Environ Safe 129:85-90

Guarrera PM (2003) Food medicine and minor nourishment in the folk traditions of Central Italy (Marche, Abruzzo and Latium). Fitoterapia 74:515-544

Herrmann F, Hamoud R, Sporer F, Tahrani A, Wink M (2011) Carlina oxide: a natural polyacetylene from Carlina acaulis (Asteraceae) with potent antitrypanosomal and antimicrobial properties. Planta Med 77:1905-1911

Hort A (1949) Theophrastus, Enquiry into Plants. Harvard University Press, London

Huang Q, Yu H, Ru Q (2010) Bioavailability and delivery of nutraceuticals using nanotechnology. J Food Sci 75:R50-R57

Isman MB (2015) A renaissance for botanical insecticides? Pest Manag Sci 71(12):1587-1590

Isman MB, Grieneisen ML (2014) Botanical insecticide research: many publications, limited useful data. Trends Plant Sci 19(3):140-145

Isman MB, Machial CM (2006) Pesticides based on plant essential oils: from traditional practice to commercialization. In: Rai M, Carpinella MC (eds) Naturally occurring bioactive compounds. Elsevier, BV, Amsterdam, pp 29-44

ISO 10993-5 (2009) International organization for standardization. In: Biological evaluation of medical devices-part 5: tests for in vitro cytotoxicity

Jaiswal R, Deshpande S, Kuhnert N (2011) Profiling the chlorogenic acids of Rudbeckia hirta, Helianthus tuberosus, Carlina acaulis and Symphyotrichum novae-angliae leaves by LC-MSn. Phytochem Anal 22:432-441

Jankowska M, Rogalska J, Wyszkowska J, Stankiewicz M (2018) Molecular targets for components of essential oils in the insect nervous system-a review. Molecules 23(1):34

Jankowska M, Lapied B, Jankowski W, Stankiewicz M (2019) The unusual action of essential oil component, menthol, in potentiating the effect of the carbamate insecticide, bendiocarb. Pestic Biochem Phys 158:101-111

Kluk K (1805) Dykcjonarz Roślinny. Drukarnia Xięzy Pijarów, Warsaw

Maggi F, Benelli G (2018) Essential oils from aromatic and medicinal plants as effective weapons against mosquito vectors of public health importance. In: Benelli G, Mehlhorn H (eds) Mosquitoborne diseases. Springer, Cham, pp 69-129

Mason TG, Wilking JN, Meleson K, Chang CB, Graves SM (2006) Nanoemulsions: formation, structure, and physical properties. J Phys Condens Matter 18:R635

McClements DJ (2012) Nanoemulsions versus microemulsions: terminology, differences, and similarities. Soft Matter 8:1719-1729

McClements DJ, Rao J (2011) Food-grade nanoemulsions: formulation, fabrication, properties, performance, biological fate, and potential toxicity. Crit Rev Food Sci Nutr 51:285-330 
Menale B, Amato G, Di Prisco C, Muoio R (2006) Traditional uses of plants in northwestern Molise (Central Italy). Delpinoa 48:29-36

OECD (2008) Guidelines for testing of chemical. Acute oral toxicity-up-and-down procedure. OECD, Paris

Pavela R (2014) Insecticidal properties of Pimpinella anisum essential oils against the Culex quinquefasciatus and the non-target organism Daphnia magna. J Asia Pac Entomol 17(3):287-293

Pavela R (2015) Essential oils for the development of eco-friendly mosquito larvicides: a review. Ind Crops Prod 76:174-187

Pavela R, Benelli G (2016) Essential oils as ecofriendly biopesticides? Challenges and constraints. Trends Plant Sci 21:1000-1007

Pavela R, Maggi F, Iannarelli R, Benelli G (2019a) Plant extracts for developing mosquito larvicides: from laboratory to the field, with insights on the modes of action. Acta Trop 193:236-271

Pavela R, Benelli G, Pavoni L, Bonacucina G, Cespi M, Cianfaglione K, Bajalan I, Morshedloo MR, Lupidi G, Romano D, Canale A, Maggi F (2019b) Microemulsions for delivery of Apiaceae essential oils-Towards highly effective and eco-friendly mosquito larvicides? Ind Crops Prod 129:631-640

Pavela R, Pavoni L, Bonacucina G, Cespi M, Kavallieratos NG, Cappellacci L, Petrelli R, Maggi F, Benelli G (2019c) Rationale for developing novel mosquito larvicides based on isofuranodiene microemulsions. J Pest Sci 92:909-921

Pavela R, Morshedloo MR, Mumivand H, Khorsand GJ, Karami A, Maggi F, Desneux N, Benelli G (2020a) Phenolic monoterpenerich essential oils from Apiaceae and Lamiaceae species: insecticidal activity and safety evaluation on non-target earthworms. Entomol Gen 40:421-435. https://doi.org/10.1127/entomologi $\mathrm{a} / 2020 / 1131$

Pavela R, Maggi F, Petrelli R, Cappellacci L, Buccioni M, Palmieri A, Canale A, Benelli G (2020b) Outstanding insecticidal activity and sublethal effects of Carlina acaulis root essential oil on the housefly, Musca domestica, with insights on its toxicity on human cells. Food Chem Toxicol 136:111037

Pavoni L, Maggi F, Mancianti F, Nardoni S, Ebani VV, Cespi M, Bonacucina G, Palmieri GF (2019a) Microemulsions: an effective encapsulation tool to enhance the antimicrobial activity of selected EOs. J Drug Deliv Sci Technol 53:101101

Pavoni L, Pavela R, Cespi M, Bonacucina G, Maggi F, Zeni V, Canale A, Lucchi A, Bruschi F, Benelli G (2019b) Green micro-and nanoemulsions for managing parasites. Vectors Pests Nanomater 9:1285

Pavoni L, Perinelli DR, Bonacucina G, Cespi M, Palmieri GF (2020) An Overview of Micro-and Nanoemulsions as Vehicles for Essential Oils: Formulation. Prep Stab Nanomater 10:135

Petrović M, Popović A, Kojić D, Šućur J, Bursić V, Aćimović M et al (2019) Assessment of toxicity and biochemical response of Tenebrio molitor and Tribolium confusum exposed to Carum carvi essential oil. Entomol Gen 38:333-348

Pignatti S (1982) Flora d'Italia. Edagricole, Bologna

Rao J, McClements DJ (2011) Formation of flavor oil microemulsions, nanoemulsions and emulsions: influence of composition and preparation method. J Agric Food Chem 59:5026-5035

Redžić SS (2007) The ecological aspect of ethnobotany and ethnopharmacology of population in Bosnia and Herzegovina. Coll Antropol 31:869-890

Rexhepi B, Mustafa B, Hajdari A, Rushidi-Rexhepi J, Quave CL, Pieroni A (2013) Traditional medicinal plant knowledge among Albanians, Macedonians and Gorani in the sharr mountains (Republic of Macedonia). Genet Resour Crop Evol 60:2055-2080
Ruelli J (1522) Pedanii dioscoridis Anazarbeii, de Medicinali materia libri sex. Lugduni, Apud Balthazarem Arnolletum, pp 329-331

Sadeghi R, Etemad SG, Keshavarzi E, Haghshenasfard M (2015) Investigation of alumina nanofluid stability by UV-vis spectrum. Microfluid Nanofluidics 18:1023-1030

Semmler FW (1889) Zusammensetzung des aetherischen Oels der Eberwurzel (Carlina acaulis L.). Chemiker Zeitung 13:1158

Stevenson PC, Isman MB, Belmain SR (2017) Pesticidal plants in Africa: a global vision of new biological control products from local uses. Ind Crops Prod 110:2-9

Stojanović-Radić Z, Čomić L, Radulović N, Blagojević P, MihajilovKrstev T, Rajković J (2012) Commercial Carlinae radix herbal drug: botanical identity, chemical composition and antimicrobial properties. Pharm Biol 50:933-940

Strzemski M, Wojnicki K, Sowa I, Wojas-Krawczyk K, Krawczyk P, Kocjan R, Such J, Latalski M, Wnorowski A, Wójciak-Kosior M (2017) In vitro antiproliferative activity of extracts of Carlina acaulis subsp. caulescens and Carlina acanthifolia subsp. utzka. Front Pharmacol 8:371

Strzemski M, Dresler S, Sowa I, Czubacka A, Agacka-Mołdoch M, Płachno BJ, Granica SMF, Wójciak-Kosior M (2020) The impact of different cultivation systems on the content of selected secondary metabolites and antioxidant activity of Carlina acaulis plant material. Molecules 25:146

Sugumar S, Clarke SK, Nirmala MJ, Tyagi BK, Mukherjee A, Chandrasekaran N (2014) Nanoemulsion of eucalyptus oil and its larvicidal activity against Culex quinquefasciatus. Bull Entomol Res 104:393-402

Tutin FG, Heywood VH, Burges NA, Moore DM, Valentine DH, Walters SM, Webb DA (1976) Flora Europea. Plantaginaceae to Compositae (and Rubiaceae). Cambridge University Press, Cambridge

Van den Dool H, Kratz PD (1963) A generalization of the retention index system including linear temperature programmed gas-liquid partition chromatography. J Chromatogr A 11:463-471

Vitkova A, Evstatieva L (2002) Plants rich inulin from family Asteraceae. Godishnik na Sofiskiya Universitet "Sv. Kliment Okhridski", Kniga 2. Botanika 92:107-111

Wilhelm KP, Cua AB, Wolff HH, Maibach HI (1993) Surfactantinduced stratum corneum hydration in vivo: prediction of the irritation potential of anionic surfactants. J Invest Dermatol 101:310-315

Wilke ABB, Beier JC, Benelli G (2020) Filariasis vector control downplayed due to the belief the drugs will be enough - not true! Entomol Gen 40:15-24

Wnorowski A, Wnorowska S, Wojas-Krawczyk K, Grenda A, Staniak M, Michalak A, Woźniak S, Matosiuk D, Biała G, Wójciak M, Sowa I, Krawczyk P, Strzemski M (2020) Toxicity of Carlina oxide-a natural polyacetylene from the Carlina acaulis rootsin vitro and in vivo study. Toxins 12:239

Wooster TJ, Golding M, Sanguansri P (2008) Impact of oil type on nanoemulsion formation and Ostwald ripening stability. Langmuir 24:12758-12765

Publisher's Note Springer Nature remains neutral with regard to jurisdictional claims in published maps and institutional affiliations. 